Columbia Law School

Scholarship Archive

Faculty Scholarship

Faculty Publications

2010

\title{
Bail-Ins Versus Bail-Outs: Using Contingent Capital to Mitigate Systemic Risk
}

John C. Coffee Jr.

Columbia Law School, jcoffee@law.columbia.edu

Follow this and additional works at: https://scholarship.law.columbia.edu/faculty_scholarship

Part of the Banking and Finance Law Commons, and the Law and Economics Commons

\section{Recommended Citation}

John C. Coffee Jr., Bail-Ins Versus Bail-Outs: Using Contingent Capital to Mitigate Systemic Risk, CoLumBIA LAW \& ECONOMICS WoRKIng PAPER No. 380 (2010).

Available at: https://scholarship.law.columbia.edu/faculty_scholarship/1654

This Working Paper is brought to you for free and open access by the Faculty Publications at Scholarship Archive. It has been accepted for inclusion in Faculty Scholarship by an authorized administrator of Scholarship Archive. For more information, please contact scholarshiparchive@law.columbia.edu. 
The Center for Law and Economic Studies

Columbia University School of Law

435 West 116th Street

New York, NY 10027-7201

(212) 854-3739

\section{BAIL-INS VERSUS BAIL-OUTS: \\ Using Contingent Capital To Mitigate Systemic Risk}

John C. Coffee, Jr.

Working Paper No. 380

October 22, 2010

An index to the working papers in the Columbia Law

School Working Paper Series is located at

http://www.law.columbia.edu/lawec/ 


\section{BAIL-INS VERSUS BAIL-OUTS:}

Using Contingent Capital To Mitigate Systemic Risk

by John C. Coffee, Jr.

Adolf A. Berle Professor of Law and Director of the Center on Corporate Governance at Columbia University Law School

October 22, 2010 
Bail-ins Versus Bail-outs: Using Contingent Capital to Mitigate Systemic Risk

by

John C. Coffee, Jr.

Adolf A. Berle Professor of Law

Columbia University Law School

$\underline{\text { Abstract }}$

Because the quickest, simplest way for a financial institution to increase its profitability is to increase its leverage, an enduring tension will exist between regulators and systemically significant financial institutions over the issues of risk and leverage. Many have suggested that the 2008 financial crisis was caused because financial institutions were induced to increase leverage because of flawed systems of executive compensation. Still, there is growing evidence that shareholders acquiesced in these compensation formulas to cause managers to accept higher risk and leverage. Shareholder pressure then is a factor that could induce the failure of a systemically significant financial institution.

What then can be done to prevent future such failures? The Dodd-Frank Act invests heavily in preventive control and regulatory oversight, but this paper argues that the political economy of financial regulation ensures that there will be an eventual relaxation of regulatory oversight ("the regulatory sine curve"). Moreover, the DoddFrank Act significantly reduces the ability of financial regulators to effect a bail-out of a distressed financial institution and largely compels them to subject such an institution to a forced receivership and liquidation under the auspices of the FDIC.

Believing that there is a superior and feasible alternative to forcing a strained, but not insolvent, financial institution into a liquidation, this paper recommends a system of "contingent capital" under which, at predefined points, a significant percentage of a major financial institution's debt securities would convert into an equity security. However, unlike earlier proposals for contingent capital, the conversion would be to a senior, non-convertible preferred stock with cumulative dividends and voting rights. The intent of this provision is to create a class of voting shareholders who would be rationally risk averse and would resist common shareholder pressure for increased leverage and risk-taking, but who would obtain voting rights only at the late stage when the financial institution enters the "vicinity of insolvency."

This paper discusses (i) the possible design of such a security, (ii) the recent experience in Europe with issuances of similar securities, (iii) tax and other obstacles, (iv) the possibility of international convergence on a system of contingent capital, and (v) the existing authority of the Federal Reserve Board to implement such a requirement. It submits that contingent capital is an idea whose time is coming, but whose optimal design remains debatable.

Keywords: bank regulation, contingent capital, Dodd-Frank Act, executive compensation, resolution authority, shareholder voting, systemic risk, "too big to fail" JEL Classifications: D21, E50, G18, G20, G21, G24, G28, G33, G38, K22, N20 
Bail-ins Versus Bail-outs: Using Contingent Capital to Mitigate Systemic Risk

by John C. Coffee, Jr.

\section{$\underline{\text { Introduction }}$}

Globally, financial regulators are confronting the problem of systemic risk namely, the risk that a localized economic shock can have worldwide repercussions because of the interconnections between financial institutions. ${ }^{1} 2008$ essentially witnessed a localized economic shock in the U.S. subprime mortgage market that nearly caused the meltdown of worldwide capital markets because that shock was transmitted rapidly through counterparties and global markets with the speed of a tsunami.

The responses of financial regulators have been diverse. In the United States, the recently enacted Dodd-Frank Act invests heavily in preventive regulation and supervision. ${ }^{2}$ New institutions are created to monitor for future shocks and direct financial firms to avoid entanglement with them. ${ }^{3}$ This is commendable, but there is a

\footnotetext{
* Adolf A. Berle Professor of Law, Columbia University Law School. The author wishes to acknowledge the assistance of his colleagues, including Merritt Fox, Ronald Gilson, Victor Goldberg, Jeffrey Gordon, Robert Jackson, Alex Raskolnikov, and Charles Sabel.

${ }^{1}$ For a fuller definition of systemic risk, see Steven L. Schwarcz, Systemic Risk, 97 Geo. L. J. 193, 204 (2008). The problem is not simply that financial institutions are interconnected (principally through the over-the-counter derivatives market), but equally that the risks they face are positively correlated. Uncorrelated risk can be solved through diversification, but if the risks financial institutions face are correlated, the failure of one is a strong signal that others are also in trouble. Moreover, if one financial institution encounters a liquidity problem and must sell illiquid assets (such as interests in asset-backed securitizations) into a thin market, this can depress asset prices and force other banks to write down similar assets on their balance sheets. Thus, the market rationally responds to the failure of one institution by discounting the stock prices of the others and ultimately cuts off short-term credit to the entire sector. That was the experience in 2008 following the bankruptcy of Lehman Brothers Holdings, Inc.

${ }^{2}$ The full title of this statute is the Dodd-Frank Wall Street Reform and Consumer Protection Act of 2010, Pub. L. 111-203 (2010) (hereinafter called the "Dodd-Frank Act"). For a fuller discussion of this statute, see text and notes infra at notes 59 to 63 and note 100 .

${ }^{3}$ For example, Section 111 of the Dodd-Frank Act creates the Financial Stability Oversight Council (the "FSOC"), which is authorized by Sections 112 through 115 to oversee systemic risk.
} 
problem: economic shocks are rarely predictable. ${ }^{4}$ And they arrive with a suddenness that often outpaces the capacity of bureaucracies to respond in a relevant fashion. More therefore must be done, and that is the topic of this article.

Just as generals fight the next war in the terms of the mistakes made in the last war, so do financial regulators focus (possibly obsessively) on the immediate causes of the last financial contagion in planning for the future. Unsurprisingly, the Dodd-Frank Act displays a special concern with executive compensation and authorizes the Federal Reserve to limit excessive compensation at significant financial institutions. ${ }^{5}$ In addition, mindful of the slow and extraordinarily costly bankruptcy reorganization of Lehman, ${ }^{6}$ the Dodd-Frank Act elaborately designs a new and hopefully expeditious liquidation procedures for a failing financial institution in order to avoid the delay and uncertainty incident to a bankruptcy reorganization. Specifically, the Dodd-Frank Act confers "resolution authority" on the Federal Deposition Insurance Corporation ("FDIC") to impose a receivership on a failing financial institution in order to achieve an "orderly

Section 165 then authorizes the Federal Reserve, either on its own or based on recommendations from the FSOC, to establish various "prudential standards," including for "contingent capital." ${ }^{4}$ For similar observations, see Iman Anabtawi and Steven L. Schwarcz, Regulating Systemic Risk, UCLA School of Law Econ. Research Paper No. 10-11 (available at http://ssrn.com/abstract=1670017) (September 20, 2010) at 3; Schwarcz, supra note 1, at 216. ${ }^{5}$ Section 956 of the Dodd-Frank Act authorizes federal banking and securities regulators to adopt rules restricting the ability of executive officers, employees or directors of "covered financial institutions" to receive "excessive compensation, fees, or benefits" or compensation that "could lead to material financial loss to the covered financial institution." The term "covered financial" includes most financial institutions (banks, investment banks, credit unions, broker-dealers, etc.) that they have assets in excess of $\$ 1$ billion.

${ }^{6}$ The administrative costs (mainly advisory and legal fees) of the still continuing bankruptcy reorganization of Lehman Brothers Holdings, Inc. has already climbed to $\$ 982$ million as of September, 2010. See Liz Moyer, “Lehman’s Bankruptcy Tab Is Close to \$1Billion.” The Wall Street Journal, October 19, 2010 at C2. This reorganization is probably still at an early stage. 
liquidation" without the investment of public funds. ${ }^{7}$ These twin concerns - restricting executive compensation and liquidating a failing financial firm quickly without a taxpayer-financed bailout - reflect two key judgments that dominated the legislative process leading up to the Dodd-Frank's enactment: namely,

(1) that the 2008 financial crisis was in substantial part the consequence of flawed executive compensation formulas that gave senior financial managers at major financial institutions perverse incentives to pursue short-term profits by accepting risk and high leverage $;^{8}$ and

(2) that financial institutions that were "too big to fail" obtained their capital at a discounted "cheap" price that reflected the market's judgment that they would never be allowed to fail, thereby encouraging these firms to undertake excessive leverage. ${ }^{9}$

\footnotetext{
${ }^{7}$ Under the Dodd-Frank Act, Congress authorized the Federal Deposit Insurance Corporation ("FDIC") to impose a receivership on a failing financial firm that will result in the firm's "orderly liquidation." The goal of this legislation is that any losses resulting from a liquidation will be imposed on unsecured creditors and shareholders, not the taxpaying public. See Title II ("Orderly Liquidation Authority"), which consists of Sections 201 to 217, of the Dodd-Frank Act. ${ }^{8}$ For a representative such statement (and by a major economist), see Alan Binder, "Crazy Compensation and the Crisis," Wall Street Journal, May 28, 2009 (describing executive compensation formulas as "one of the most fundamental causes" of the crisis); for the more general argument that executive compensation formulas created gave rise to a moral hazard problem, see Lucian A. Bebchuk and Holger Spamann, Regulating Bankers' Pay, 98 Geo. L. Rev. 247 (2010).

${ }^{9}$ The following summary reflects the consensus view of the "too big to fail" phenomenon:

"Explicit or implicit government guarantees immunize the banks' creditors against the consequences of a default by the bank. As a result, the default risk premium in the interest rates demanded by the banks' creditors is lower and may even be zero. Institutions that benefit from such guarantees, e.g., institutions that are deemed to be "too big to fail," are therefore able to borrow at lower interest rates. The savings in capital costs that are thereby achieved are the larger the more leverage the bank has." See Anat R. Admati, Peter DeMarzo, Martin Hellwig, Paul Pfleiderer, "Fallacies, Irrelevant Facts, and Myths in the Discussion of Capital Regulation: Why Bank Equity is Not Expensive," Stanford
} 
Neither of these premises is wrong, but Dodd-Frank's response to them may represent a myopic overreaction for two basic reasons:

First, executive compensation formulas may well have incentivized managers to accept excessive risk, but this shift toward greater risk occurred not because managers overreached shareholders, but rather because shareholders used executive compensation as a means of inducing managers to accept levels of risk and leverage that they would otherwise have resisted. Flawed executive compensation was more an effect than a cause, and shareholders were more instigators than victims. At a minimum, managers and shareholders have different and often conflicting interests. Because they are generally diversified, shareholders have far greater willingness to tolerate risk (and to pressure for increased leverage) than do undiversified managers.

More generally, heightened systemic risk is but another example that the unconstrained shareholder pursuit of wealth maximization can lead to externalities. Pollution is usually given as the standard example of an externality, as the polluting corporation escapes the full social costs that it creates. Conceptually, heightened systemic risk similarly involves costs that are externalized by the firm and fall instead on society. ${ }^{10}$ Over the short-run, the quickest way for a financial institution to increase its profitability is to increase its leverage. Because many institutional shareholders must compete for investors' funds, they may pursue wealth maximization strategies more aggressively than

GSB Research Paper No. 2065 (September 30, 2010) (available at http://ssrn.com/abstract=1669704), at 19.

${ }^{10}$ Of course, the firm bears some of the costs (particularly if it fails). But, for example, when a distressed financial institution dumps assets on a thin market in order to raise capital, it depresses asset values and hence reduces the market value of other financial institutions. And if its own bankruptcy cause other failures (or necessitates public bailouts of other firms - as Lehman's failure arguably did), then it also imposes costs on society. 
other shareholders (and hence may tolerate more externality-creating behavior, including higher leverage). The key implication here is that the level of risk that is privately optimal for the shareholders of a financial institution may not be socially optimal. Accordingly, shareholder pressure that heightens systemic risk should be seen less as a problem of governance, and more as a problem of externalities.

Second, although the "too big to fail" phenomenon does generate a "moral hazard" problem, that problem cannot be addressed in isolation and cannot justify exacerbating the risk of the "falling dominoes" scenario under which the first financial firm to fail sets off a cascade of successive failures. A consensus probably exists among economists that the market's perception that some financial institutions were "too big to fail" (and would therefore be bailed out, if necessary, with public funds) resulted in a subsidy for these institutions because their creditors charged them less for capital than their true risk level justified. ${ }^{11}$ As a result, because they paid too little for their capital, these firms (and their shareholders) were incentivized to take on excessive leverage. But the Dodd-Frank Act may overreact to this problem by denying banking regulators their traditional ability to advance funds to a major financial institution facing a liquidity crisis. Because liquidity crises are a recurring (and perhaps inevitable) phenomenon in the field of banking, restrictions that deny banking regulators the capacity to stave off such a crisis by advancing funds to a troubled firm may impose a dangerous straitjacket on regulators - and could be exactly the kind of policy capable of turning a localized economic shock into a worldwide financial crisis. Thus, to the extent that the Dodd-Frank Act strips regulators of their traditional powers by which to avert a panic, public policy must devise

\footnotetext{
${ }^{11}$ See Admati, DeMarzo, Hellwig, Pfleiderer, supra note 9, at 19.
} 
a substitute mechanism by which to prevent a localized shock from causing a cascade of falling financial dominoes.

Modern "law and economics" suggests that the appropriate policy response to this tendency for "too big to fail" financial institutions to obtain capital too cheaply is to impose a "bank tax" on them in order to offset this implicit subsidy. ${ }^{12}$ As the International Monetary Fund has advocated in the wake of the 2008 crisis, ${ }^{13}$ such a "bank tax" would "pre-fund" a private global emergency fund that could bail out a threatened systemically significant financial institution. Thus, a private, industry-funded bailout (paid for by the bank shareholders who benefitted from the subsidized interest costs) would substitute for a public bailout (paid for by taxpayers). Ideally, such a "bank tax" would not only prevent the "falling dominoes" scenario, but would reduce the incentive of shareholders to favor a socially undesirable level of leverage.

Still, sound as such a policy might be, it has proven to be politically toxic. ${ }^{14}$ Late in the drafting of Dodd-Frank, the Conference Committee struck proposals for any such

\footnotetext{
${ }^{12}$ Put simply, the tax should force the firm to internalize the costs that it is imposing on society. For an in depth examination of such a proposal (and a critique of the Dodd-Frank Act), see Jeffrey N. Gordon and Christopher Muller, Confronting Financial Crisis: Dodd-Frank's Dangers and the Case for a Systemic Emergency Fund, Columbia Center for Law and Economics Studies Working Paper No. 374 (available at http://ssrn.com/abstract=1636456 (August 15, 2010)). Of course, the idea of such a private insurance fund funded by the relevant industry is not new and provided the rationale for both the Federal Deposit Insurance Corporation and the Securities Insurance Protection Corporation, which protect depositors and investors from the failure of banks and brokers, respectively.

${ }^{13}$ The International Monetary Fund has proposed a levy on banks - known as a "financial stability contribution" - to generate a self insurance fund equivalent to 4-5\% of each country's GDP; this fund would total around $\$ 1$ to 2 trillion. See Linda Yueh, "IMF Gets Tough on Banks With "FAT" Levy," Guardian Unlimited, April 21, 2010.

${ }^{14}$ The idea of such a bank tax is controversial not only in the United States, but in Europe as well. See Alstair Dawber, "EU Finance Ministers Fail to Agree on Bank Tax; UK and EU Finance Chiefs at Loggerheads Over How to Use the Proceeds of a Levy," The Independent (London), April 19, 2010 at 38 (reporting disagreements at meeting of EU Finance Ministers).
} 
private bailout fund from the final legislation. To an angry public, any suggestion of bailout of failed financial institutions has been unacceptable. Moreover, critics of such a fund believe that the very existence of such a bailout fund might encourage "complacency" on the part of the insured banks, with the result that investors might again favor excessive leverage. ${ }^{15}$ If that were the case, the same "moral hazard" problem would surface in a new form, and externalities would again result. Hence, more is needed than simply a private bailout fund.

The Dodd-Frank Act's basic approach to the problem of systemic risk is to mandate and rely on active regulatory monitoring and oversight, while simultaneously denying regulators (in the name of preventing "moral hazard") any authority to advance funds to a threatened financial institution that is not to be liquidated. Although greater regulatory oversight is certainly desirable, this article will argue that exclusive reliance upon it is unwise and paints financial regulators into the proverbial corner. Because of a variety of factors - the inherent fragility of financial institutions, the interconnections among them and the closely correlated risks that they face, and finally the political economy of financial regulation - it is unfortunately predictable that serious problems capable of generating a systemic crisis will not be detected in advance or will elicit only an inadequate response. If $\underline{\text { ex }}$ ante preventive regulation is likely to fail (at least eventually) and if banking regulators are stripped of their authority to advance funds to

\footnotetext{
${ }^{15}$ See Yueh, supra note 13 (noting that a key objection to the bank tax was that it would encourage "complacency" on the part of the insured banks). This complacency could result in part from the belief that, if the private fund were inadequate, it would need to be supplemented by public funds. Even if public funds were not made available and bankruptcies resulted, then costs would again be visited on society.
} 
troubled financial firms ex post (as the Dodd-Frank Act has largely done ${ }^{16}$ ), the result could be a financial catastrophe worse than the 2008 crisis.

What can be done to avert such a systemic crisis? Even if a private bailout emergency fund is a partial answer, the prospects for its adoption in the U.S. are dim at best. Moreover, such a fund does not fully respond to the problem of shareholder pressure. ${ }^{17}$ In overview, the goal for public policy must be to make the financial system more resilient to localized economic shocks in order that a crisis at one financial firm does not generate a cascading series of failures by interconnected financial institutions. To create such a buffer that prevents the failure of one significant firm from carrying its interconnected cohorts down with it, this article proposes a mandatory change in the capital structure of systemically significant financial institutions. The proposal that it favors - known as "contingent capital" - has both strong advocates and skeptical critics. Among the former are the Association for Financial Markets in Europe ("AFME"), ${ }^{18}$ Canada's principal bank regulator, ${ }^{19}$ the Squam Lake Working Group, ${ }^{20}$ and, potentially,

\footnotetext{
${ }^{16}$ See text and notes infra at notes 59 to 63 .

${ }^{17}$ Even in the case of ordinary industrial corporations, activist shareholders regularly pressure for increased leverage. Hence, because these companies are not "too big to fail" and do not receive an interest rate subsidy based on investor expectations of a bailout, it cannot be said that eliminating that subsidy will alone eliminate shareholder pressure for increased leverage. ${ }^{18}$ See Mark Austen, "Too Big to be Bailed Out: There is a Way to Rescue Banking Giants and the Economy Without Making the Taxpayer Cough Up," The Guardian, August 17, 2010 at p. 26 (reporting endorsement by AFME).

${ }^{19}$ Canada's Office of the Superintendent of Financial Institutions (“OFSI") has announced a policy of requiring all subordinated debt issued by financial institutions under its jurisdiction to contain a conversion provision under which the debt will convert into equity under specified circumstances of financial distress. See Blair Keefe, "Canada Pushes Embedded Contingent Capital," Mondaq, August 25, 2010.

${ }^{20}$ Kenneth R. French, et al., THE SQUAM LAKE REPORT: Fixing the Financial System (2010) (Princeton University Press). The Squam Lake Working Group includes a collection of prominent financial economists from major universities and elsewhere.
} 
the Financial Stability Board and the Basel Committee on Banking Supervision. ${ }^{21}$ On the other side of the debate, some academic critics contend that contingent capital is either infeasible or an overly complex substitute for simply requiring the infusion of more equity capital into systemically significant financial institutions. ${ }^{22}$

Contingent capital is not an abstract academic idea, nor is the debate over its design remote and theoretical, because a little noticed provision in the Dodd-Frank Act authorizes the Federal Reserve to adopt a "contingent capital standard."23 Thus, contingent capital is a relevant policy option, already available to regulators, but its optimal design remains open to legitimate and necessary debate. Here, rather than take either side of the existing debate, this article proposes a significant redesign of the contingent capital concept. To date, proposals for contingent capital have only required that the financial institution issue a percentage of its long-term debt capital in the form of a convertible debt security that would automatically convert into equity as the institution's financial condition weakened. This mandatory conversion feature means that the debt security would not default and thus bankruptcy would be avoided. More importantly, because the first domino would not fall, the cascade scenario of multiple

\footnotetext{
${ }^{21}$ See Adam Bradbery, "Bondholders Face a Push to Impose Bank Bail-Ins," The Wall Street Journal, August 25, 2010 (reporting that the Financial Stability Board is tentatively favoring the idea); Damien Paletta, “Idea to Prevent Next Banking Bust?" Wall Street Journal, September 27, 2010 (noting support of Basel Committee and CEO of Goldman, Sachs).

${ }^{22}$ For the view that contingent capital (as presently designed) serves mainly to preserve taxadvantaged financing and is an inferior policy to requiring greater equity capital, see Anat R. Admati, Peter M. DeMarzo, Martin Hellwig, Paul Pfleiderer, Fallacies, Irrelevant Facts, and Myths in the Discussion of Capital Regulation: Why Bank Equity Is Not Expensive, Stanford GSB Research Paper No. 2065 at pp. 45-49 (available at http://ssrn.com/abstract=1669704 (September 30,2010). These authors further contend that the financial industry is attracted to proposals for contingent capital because they view it as a way of preserving the tax advantages of debt financing (whereas the use of equity capital is viewed by the industry as too expensive). ${ }^{23}$ See Section 165(b)(1)(B) of the Dodd-Frank Act (discussed infra in text and notes at notes 99 to 100). The Federal Reserve Board must, however, study the idea and approve its feasibility.
} 
firms failing in succession would be averted. Still, as generally contemplated, the holders of the debt security would still suffer a significant loss. ${ }^{24}$

Converting debt to equity in this contingent fashion makes sense because it avoids the costs, delay and uncertainty of a bankruptcy proceeding, while (1) scaling down the firm's debt burden when necessary and (2) still permitting the firm to use tax-advantaged debt financing. ${ }^{25}$ In essence, a pre-planned contract replaces the bankruptcy process and gives greater certainty. All this may be sensible, but it still does not address the key factor that leads issuers to take on excessive leverage: namely, shareholder pressure. To reduce shareholder pressure, more must be done, and the design here proposed for contingent capital deviates from earlier proposals in two significant ways: (1) the conversion ratio would be deliberately designed to protect the debt holders from loss by instead diluting the existing equity holders; and (2) the debt security would convert into a fixed return preferred stock with cumulative arrearages and significant voting rights. Because the new preferred stock would have only a limited return and not share in the firm's residual earnings, the interests of the preferred stockholders would be naturally aligned with those of the firm's debt holders. These preferred shareholders would be rationally risk averse, and they would have significant voting rights. The goal behind this use of preferred stock is to create a countervailing voting constituency to offset the voting power of risk-tolerant common shareholders, thereby reducing the pressure on corporate managers to accept greater risk and leverage.

\footnotetext{
${ }^{24}$ Since the 2008 crisis, there have already been two issuances of contingent capital in Europe, and in each the debt holders would face a significant writedown on conversion. See infra at notes 67 and 73.

${ }^{25}$ Debt financing carries tax advantages because interest expense is deductable, while dividends on any form of equity security are not. [add IRS Code citation]
} 
As so redesigned, it is not necessary that a conversion of the debt security actually occur for contingent capital to have a disciplining impact on the common shareholders and deter excessive risk-taking. As proposed, conversion would occur at several stages when prescribed tests were triggered. The market would understand that, at these clearly defined trigger points, conversion would become mandatory and would dilute both the common shareholder's cash flow and voting rights. Even to approach these trigger points and the wealth transfers that they would entail from common shareholders to the former debt holders would adversely affect the market price of the issuer's common stock. Thus, even if the market (and common shareholders) might otherwise favor increased leverage, this risk of the common stock's dilution on conversion of the debt security should counterbalance that pressure.

Because shareholder pressure is at the center of this explanation for why financial institutions failed in 2008 , it is important to stress at the outset the differences between the foregoing account of the 2008 crisis and the more conventional story. In the standard story, managers are assumed to have overreached more cautious and prudent shareholders because the incentives of managers were geared to the short-term and towards risk preference as the result of compensation formulas that they designed. ${ }^{26}$ This overstates. In truth, shareholder pressure usually influences managerial preferences, and modern corporate governance has increasingly reduced the "agency costs" that once enabled managers to resist or disdain shareholder pressure. As later discussed, the more

\footnotetext{
${ }^{26}$ For basically such an account, see Lucian A. Bebchuk and Holger Spamann, Regulating Bankers' Pay, 98 Geo. L. Rev. 247 (2010) (arguing that moral hazard problem was created by executive compensation formulas that allowed senior executives to share in gains with shareholders but avoid losses); see also, Lucian A. Bebchuk, Alma Cohen, and Holger Spamann, The Wages of Failure: Executive Compensation at Bear Stearns and Lehman 2000-2008, 27 Yale J. of Regulation 257 (2010).
} 
"shareholder friendly" the firm's corporate governance system, the less attention likely to be paid to externalities, and the greater the exposure to volatility and systemic risk. ${ }^{27}$

In contrast to shareholders, managers tend to be more risk averse. ${ }^{28}$ This is both because they (1) face greater legal and reputational risks from a corporate failure than do shareholders, and (2) suffer more economically from a failure because managers, almost by definition, are undiversified and tend to have significant firm-specific capital invested in their firms. This claim is hardly new. Indeed, a well-known literature in corporate finance has argued that managers tend to hoard "free cash flow" (i.e., cash that could be used for shareholder distributions), and have historically resisted shareholder pressure for greater dividends. ${ }^{29}$ Inefficient as such "free cash flow" hoarding may be in the general corporate context, it could be more desirable in the case of major financial institutions because it implies increased capital reserves and thus reduces the risk of a major bankruptcy that might set off a cascade of interconnected financial failures.

This article therefore focuses on how corporate governance at systemically significant financial institutions might be revised to mitigate shareholder pressure. Although regulators should also seek to resist such shareholder pressure, it will be argued that, even under the best designed system of regulatory oversight, regulatory activism is

\footnotetext{
${ }^{27}$ For empirical evidence supporting this proposition, see text and notes infra at notes 34 to 40 .

${ }^{28}$ This is traditionally cited as one reason that managers resist takeovers and "going private" transactions, which involve greater leverage. I have explored this theme at length elsewhere. See Coffee, Shareholders Versus Managers: The Strain in the Corporate Web, 85 Mich. L. Rev. 1 (1986).

${ }^{29}$ This literature begins with Michael C. Jensen, Agency Costs of Free Cash Flow, Corporate Finance, and Takeovers, 76 American Economic Review, Papers and Proceedings, 323 (1986). Of course, the ability to hoard "free cash flow" declines, as corporate governance became more shareholder friendly.
} 
likely to subside once the economy returns to an apparent normalcy. Hence, without accepting regulatory failure, society must still anticipate it and adopt failsafe measures.

The roadmap for this article follows from these contentions. Part I will examine the impact of shareholder pressure as the force most logically explaining the shift toward excessive risk-taking and leverage at financial firms. Although this pressure exists at all corporations, it seems more intense at large financial firms where shareholders rationally want their managements to exploit the opportunity to borrow at below-market interest rates because of the market's perception that these firms are "too big to fail." Part II will then turn to the political economy of financial regulation and the predictability of a future systemic failure. It posits the inevitability of a "regulatory sine curve" under which regulatory activism, while intense in the wake of a regulatory crisis, relaxes thereafter, as lobbying and the impact of regulatory arbitrage soften the resistance of regulators. From this premise and the premise that liquidity crises are endemic to banking, it follows that, as strip regulators of the power to advance funds to banks caught in such a liquidity crisis, we must find some substitute that insulates the financial system so that a local shock cannot cause a financial panic.

The bottom line then is that regulatory strategies are needed that go beyond traditional "safety and soundness" regulation. Neither preventive regulation nor an expedited liquidation process (which are the principal tools that the Dodd-Frank Act gives to financial regulators) are alone sufficient. Part III will then turn to its preferred strategy - the mandatory use of contingent capital - and explains that its greatest strength is that it can work even when regulatory oversight fails and problems sneak in under the regulator's radar screen. Contingent capital is not presented as a panacea or as adequate 
remedy by itself. Yet, if we recognize both that some regulatory failures are inevitable and that the interconnections among financial firms may lock the financial industry into a downward spiral if any major firm fails, a failsafe option should be designed in advance.

A final and even deeper premise to this article is that, in the case of major financial institutions, governance arrangements cannot be simply the product of private negotiations among shareholders, managers and other corporate constituencies. Private optimality and social optimality deviate. Banks are different - because the public inevitably stands behind them as their guarantors of last resort. Nonetheless, the proposals here advanced are conservatively designed to give creditors voting power only once the corporation enters the "vicinity of insolvency,"30 and they do not generally seek to override the shareholders' power to determine corporate policy. Because creditors are by no means the champions of economic efficiency, voting power is conferred on them only in limited circumstances as the least restrictive alternative by which to control the potential externalities that arise in a world of very interconnected financial institutions and markets.

\section{The Significance of Shareholder Pressure}

The conventional story of the 2008 crisis - as best told by Professor Lucian Bebchuk and his co-authors $^{31}$ - focuses on the perverse influence of executive

\footnotetext{
${ }^{30}$ This phrase, used by Chancellor William Allen in Credit Lyonnais Bank Nederland N.V. v. Pathe Communications Corp., 1991 Del. Ch. 215, at *100 (Del. Ch. 2991), has long served as a shorthand term for the undeniable economic fact that shareholders have perverse incentives to take high risk (at the expense of creditors) when their corporation is on the doorsteps of insolvency.

${ }^{31}$ See Lucian A. Bebchuk and Holger Spamann, Regulating Bankers' Pay, 98 Georgetown L. Rev. 247 (2010); Lucian A. Bebchuk, Alma Cohen, and Holger Spamann, The Wages of Failure: Executive Compensation at Bear Stearns and Lehman, 2008-2008, 27 Yale Journal on Regulation 257 (2010).
} 
compensation. They argue not only that executive pay packages excessively focused on short-term results, but that because senior executive compensation packages were closely tied to highly levered bets on the value of the banks' assets, senior executives shared in any shareholder gains, but were insulated from shareholder losses. ${ }^{32}$ Hence, they could focus on the upside and ignore the downside of any risky strategy. The result, they argue, is a classic moral hazard problem.

To corroborate their claim, Bebchuk and his co-authors have collected data showing that senior managers appeared to have profited handsomely even when shareholders lost virtually everything. Examining the failures of Bear Stearns and Lehman, they find that the top-five executives teams at each firm cashed out extraordinary amounts of performance-based compensation during the 2000-2008 period. Specifically, they estimate that these top-five management teams derived $\$ 1.4$ billion and $\$ 1$ billion, respectively, from cash bonuses and equity sales during this period. ${ }^{33}$ These amounts substantially exceeded the same executives' stock holdings at the beginning of the period. If managers win when shareholders lose, this evidence would seem to confirm Bebchuk's moral hazard diagnosis.

Their research has not, however, gone unchallenged. In particular, Rene Stulz has coauthored several papers that dispute this thesis that the executive compensation formulas for senior executives at financial institutions drove the 2008 crisis by creating an excessive incentive to accept risk. ${ }^{34}$ In one paper, he and a coauthor find evidence that

\footnotetext{
${ }^{32}$ See Bebchuk and Spamann, supra note 30, at 249-250.

${ }^{33}$ See Bebchuk, Cohen \& Spamann, supra note 30, at 2.

${ }^{34}$ See Rudiger Fahlenbrach and Rene M. Stulz, Bank CEO Incentives and the Credit Crisis, Dice Center Working Paper No. 2009-13 (available at http://www.ssrn.com/abstract=1439859) (July 2009); Andrea Beltratti and Rene M. Stulz, Why Did Some Banks Perform Better During the
} 
those banks with chief executive officers ("CEOs") whose incentives were better aligned with their shareholders actually performed worse during the crisis. ${ }^{35}$ Further, they find that banks with higher option compensation and a larger fraction of CEO compensation in cash bonuses did not perform worse. ${ }^{36}$ Nor do they find that bank CEOs reduced their stock holdings prior to 2008; hence, they suffered large wealth losses along with the shareholders. ${ }^{37}$

In another study, Stulz and a co-author find that banks with "shareholderfriendly" corporate governance performed worse during the 2008 crisis. ${ }^{38}$ Indeed, banks that the market had favored in 2006 had especially poor returns during the crisis. ${ }^{39}$ In other words, financial institutions that led the market in 2006 encountered disaster in 2008. In contrast, financial institutions that had seemed stodgy and unresponsive to shareholder desires in 2006 experienced the least losses in 2008. Such findings are at least consistent with the view that shareholder pressure led managers to take on higher leverage and accept greater risk in the boom years - with catastrophic consequences later in 2008. Shareholders in effect opted for a financial roller coaster, and the firms they could control soared to record peaks and plunged to deep valleys in rapid succession.

Credit Crisis? A Cross-Country Study of the Impact of Governance and Regulation, Dice Center Working Paper No. 2009-12, (available at http://www.ssrn.com/abstract=1433502) (July 13, 2009).

${ }^{35}$ See Fahlenbrach and Stulz, supra note 34, at 1-2 (arguing that the most plausible explanation for these findings is that CEOs "took actions that they believed the market would welcome," but "ex post, these actions were costly to their banks").

${ }^{36}$ Id. at 2.

${ }^{37}$ Id. at 2, 4.

${ }^{38}$ Beltratti and Stulz, supra note 34, at 2.

${ }^{39} \mathrm{Id}$. at 2. Banks that performed in the worst quartile of performance during the 2008 crisis had average returns of $-87.44 \%$ during the crisis, but an average return of $+33.07 \%$ in 2006 . The best performing banks during the crisis had average returns of $-16.58 \%$ during the crisis, but only average returns of $+7.80 \%$ in 2006 . 
Still another study by a different team of researchers has also found that "owner controlled" banks had higher profits in the years before the 2008 crisis in comparison to "manager-controlled" banks, but experienced larger losses and were more likely to require governmental assistance during the 2008 crisis. $^{40}$ As with Stultz's study, such evidence suggests that to the extent managers possess discretion, they will tend to avoid high risk and leverage, but when their preferences can be overridden by shareholders, they will be compelled to accept greater risk and will suffer worse losses in a crisis.

Does this research disprove the claims of Bebchuk and his colleagues? That is not this paper's contention. Bebchuk and his colleagues argue that the pay formulas used to compensate senior management at banks give them an excessive incentive to accept risk. But such an increased incentive could be exactly what shareholders wanted. Shareholders have long used executive compensation to align managerial preferences with their own, and institutional investors certainly understand that managers are undiversified and thus risk averse about corporate insolvency. Thus, to "correct" this tendency, shareholders could have been willing to accept even imperfect compensation formulas to seduce managers into accepting increased risk. Thus, both sides in this debate could have valid points. Bebchuk and company could be correct that compensation formulas create excessive incentives for bank managers to engage in risky activities, and Stulz and others can legitimately interpret their own data to mean that shareholder-controlled firms accept higher risk and are more prone to failure in a crisis that firms in which managers are free to enjoy the quiet life (and so avoid risk). Rather than managers overreaching

\footnotetext{
${ }^{40}$ See Reint Gropp and Matthias Kohler, Bank Owners or Bank Managers: Who Is Keen on Risk? Evidence from the Financial Crisis (available at http://ssrn.com/abstract=1555663) (February 23, 2010).
} 
shareholders, it looks instead as if manager incentives have been at least crudely aligned with those of their shareholders by these compensation formulas. Under this synthesis, shareholders, as principals, simply found ways to contract with managers, as their agents, to accept greater risk through lucrative compensation formulas.

But that only brings us back to the centrality of shareholder pressure and the gap in bank governance between what is privately optimal and what is socially optimal. Arguably, shareholders of financial institutions were willing to accept high leverage and risk, not simply because they were diversified, but because they believed that (1) major banks are either "too big to fail" or "too interconnected to fail," and (2) the implicit reduction in interest expense charged to "too big to fail" banks created an opportunity for "cheap" capital that could not be spurned. Based on these beliefs and expectations, shareholders of major financial institutions could rationally pressure management to accept more risk than shareholders might consider advisable at industrial corporations.

To be sure, the shareholders may have been surprised when the government did not intervene (as it did not in the case of Lehman). But, more typically, the federal government arranged shotgun marriages through mergers to save insolvent financial institutions (as they did in the case of Bear Stearns, Merrill Lynch and Wachovia during the 2008 crisis). Thus, even if shareholders were not protected in these cases, creditors were, and as a result the implicit subsidy in interest rates may remain. If so, this should continue to motivate shareholders to pursue "cheap" sources of financing at the price of excessive leverage.

The bottom line here is that so long as some major banks are perceived to be "too big to fail," their shareholders will have rational incentives to take undue risk from the 
perspective of social optimality - because the risk will be externalized and borne at least in part by taxpayers and others. One can ascribe the relative indifference of shareholders to the risk of failure by a financial institution to a variety of possible causes: (a) a belief that the government will not allow major banks to fail; (b) a lesser level of risk aversion because shareholders are diversified, or (c) the possibility that proactive equity shareholders see short-term gains from increasing leverage and believe they can exit the firm before it encounters financial distress. It is not necessary to choose a preferred theory, as all lead to the same bottom line: public policy must seek to counteract the excessive shareholder tolerance for risk in the case of major financial institutions. A focus that is limited to regulating managerial compensation is myopic, because even if compensation had been strictly regulated by the Dodd-Frank Act (and it was not), shareholders of financial institutions could find other means by which to pressure and incentivize their managements.

Worse yet, the Dodd-Frank Act has increased the ability of shareholders to pressure managers to increase leverage and accept greater risk. It expressly authorized the SEC to adopt rules giving shareholders "access to the proxy statement," that dissidents can mount campaigns for minority seats on the board without having to undertake costly proxy fights. The SEC responded to this invitation by quickly adopting new Rule 14a-11, which potentially enables dissident shareholders to place their nominees on the corporate board at low cost. ${ }^{42}$ Rule $14 a-11$ may be a desirable

\footnotetext{
${ }^{41}$ See Section 971 ("Proxy Access") of the Dodd-Frank Act.

${ }^{42}$ See Securities Act Release No. 33-9136 ("Facilitating Shareholder Communication") (August $25,2010)$. Specifically, if a holding period and certain other conditions are satisfied, the new rule will permit shareholders holding $3 \%$ or more of the voting power to nominate one or more candidates for election as directors, as alternative candidates to those nominated by the Board's
} 
counterweight to entrenched managerial power in the case of much of Corporate America, but again financial institutions are a special case. Given the natural tension between the social interest in prudent bank regulation and the shareholder interest in profit maximization through higher leverage, corporate governance reforms that enhance shareholder power may at the same time weaken regulatory control over financial institutions. Specifically, the specter of hedge funds and other proactive investors using their new proxy access powers to place their candidates on the boards of major banks should give one pause, because it will be a likely prelude to those same activists pressuring for increased leverage.

\section{The Predictability of Systemic Failures}

Even if implemented decisively and administered prudently (neither of which can be safely assumed), the Dodd-Frank Act will still not prevent the failure of another systematically significant financial institution. Why not? The answer stems from three interrelated factors: (1) inherent bank fragility; (2) a regulatory sine curve under which a period of rigorous regulatory scrutiny following a market crash is followed by increasing relaxation of the rules and typically capture of the regulator (at least to some degree) by the industry; and (3) cognitive limitations on the ability of both private gatekeepers and public regulators to perceive new risks accurately (before it is demonstrably too late). This claim that systemic failures will recur may sound overly provocative and unsupported, but it is simply a distillation of what financial historians have recurrently

nominating committee; the insurgent shareholders may place the names of their candidates on the corporation's own proxy statement, thereby sparing the insurgents many of the costs of a proxy contest. Rule 14a-11 has been temporarily suspended by the SEC pending legal challenges to its adoption. [citation] 
reported. From the classic work of Charles Kindleberger ${ }^{43}$ to more recent work by Carmen Reinhart and Kenneth Rogoff, whose aptly named book, "THIS TIME IS DIFFERENT: Eight Centuries of Financial Folly, ${ }^{, 44}$ expresses the essential point, the same theme recurs: human beings have bounded rationality and will predictably be blindsided by a new crisis.

Accordingly, this section will attempt only a brief overview of ground that other scholars have recently ploughed at greater depth:

A. Bank Fragility. Banks (and similar financial institutions) are subject to a fundamental mismatch between the short-term character of their liabilities and the longerterm character of their assets. ${ }^{45}$ Depositors expect and receive high liquidity, while borrowers expect to repay their loans over a multi-year period. In good times, banks profit from this "maturity transformation," realizing the spread between the lower rate paid depositors and the higher rate charged borrowers. But, in bad times, banks have been classically subject to "runs" when depositor confidence is shaken. ${ }^{46}$ To maintain investor confidence and avert runs, bank regulators engage in "safety and soundness" regulation that is designed to convince depositors that their bank can handle sudden increases in the rate of depositor withdrawal.

\footnotetext{
${ }^{43}$ See Charles P. Kindleberger, MANIAS, PANICS AND CRASHES (1975).

${ }^{44}$ Carmen M. Reinhart \& Kenneth Rogoff, THIS TIME IS DIFFERENT: Eight Centuries of Financial Folly (2009).

${ }^{45}$ For an overview, see Richard A. Posner, A FAILURE OF CAPITALISM: The Crisis of '08 and the Descent Into Depression at 128-130 (2009).

${ }^{46}$ For standard accounts of this tendency, see Douglas W. Diamond \& Philip H. Dybvig, Bank Runs, Deposit Insurance and Liquidity, 91 J. Pol. Econ. 401 (1983); Charles W. Calomiris \& Joseph R. Mason, Fundamentals, Panics and Bank Distress During the Depression, 93 Amer. Econ. Rev. 1615 (2003). Gordon and Muller provide a concise summary of this literature. See Gordon and Muller, supra note 12, at 7 to 13.
} 
To be sure, a traditional bank run did not cause the 2008 financial crisis, but panic may have played a role. The rise of derivatives and asset-backed securitizations were the two most distinctive new elements that explain the 2008 crisis, and derivative trading, particularly in the case of credit default swaps, tied together major financial institutions as counterparties, so that the failure of one could cause the failure of others. In the standard phrase, banks became "too interconnected to fail."

Banks also became "interconnected" in another sense. Over the decade prior to 2008, most had invested heavily in asset-backed securitizations and profited handsomely by underwriting these new classes of securities. Either because they also invested in these securities or just had deals in the pipeline, their balance sheets were heavily laden with such securities. Thus, when Bear Stearns effectively failed in early 2008, it was obvious that the other major investment banks - particular, Lehman, Merrill Lynch and Citigroup, which had all aggressively pursued the same business strategy - were all vulnerable as well. ${ }^{47}$ To sum up, it oversimplifies to say that major banks are "too big to fail," they are also "too interconnected to fail" and "too correlated to fail."

Although investment banks are different from commercial banks in that they do not have depositors, they are at least as subject to the same mismatch of short-term liabilities and long-term assets, because typically they finance their operations with short-

\footnotetext{
${ }^{47}$ A core aspect of systemic risk is that risks are correlated. See supra note 1. If banks are known to be following similar policies or have made similar investments, then financial distress at one implies likely financial distress at others. Particularly when transparency is lacking, market participants may be unwilling to advance funds or extend credit to other financial institutions based on these "similarity" concerns. See Anabtawi and Schwarcz, supra note 4, at 26; Gordon and Muller, supra note 12, at_.
} 
term, often overnight borrowings in the "repo" market. ${ }^{48}$ Thus, when the market suspects that a financial institution is subject to a risk of insolvency, short-term creditors may stage their own bank "run" by refusing to renew short-term credit lines or vastly increasing the interest rate. This functional equivalent to a "run" by depositors appears to have happened not only at Bear Stearns and Lehman, but across the banking system in 2008. ${ }^{49}$ Gary Gorton has argued that the 2008 panic was different than most earlier panics in the $19^{\text {th }}$ and early $20^{\text {th }}$ Centuries in that it was a "wholesale" panic, not a "retail" panic, because the market suddenly learned that the banking system as a whole had become insolvent. $^{50}$

This panic was aggravated by asymmetric information. Because derivatives traded in non-transparent "over-the-counter" markets, few knew what the counterparty exposures of other institutions were. Lacking accurate knowledge, banks cut back on lending, and for a time the banking system froze..$^{51}$

Because of the dependence of banks on short-term financings, the end comes quickly for a financial institution that loses credibility with the market. Correspondingly, time is of the essence in any effort to structure either a bailout or a merger to prevent a

\footnotetext{
${ }^{48}$ The term "repo" refers to "repurchase agreements," which usually involve highly liquid, investment grade securities that the borrower sells to the creditor at a slight discount but agrees to repurchase at a higher price on a very short-term basis. For discussion of the repo market and its destabilizing impact on the contemporary banking system, see Gary Gorton and Andrew Metrick, Regulating the Shadow Banking System (available at http://ssrn.com/abstract=1676947) (September 10, 2010).

${ }^{49}$ See Gary Gorton, Slapped in the Face by the Invisible Hand: Banking and the Panic of 2007 (available at http://ssrn.com/abstract=1401882) (May 9, 2009).

${ }^{50}$ See Gorton, supra note 49, at 37 to 38.

${ }^{51}$ See Victoria Ivashina \& David S. Scharfstein, Bank Lending During the Financial Crisis of 2008 (available at http://ssrn.com/abstract=1297337) (July 2009) (finding that new loans to large borrowers fell by $47 \%$ in the fourth quarter of 2008 in comparison to prior quarter, as banks cut back lending).
} 
panic-inducing insolvency. When Bear Stearns began to collapse on Friday, March 14, 2008, the Federal Reserve had only a weekend to negotiate a merger between it and JP Morgan Chase. No merger candidate could be found for Lehman within similar time constraints. Resolution authority may give regulators more time, but how much time depends on how early they recognize the crisis. Both in the case of Bear Stearns and Lehman, regulators appear to have been unaware of the depth of the problems at both firms until relatively near the end. Given this tendency to recognize and react to an approaching crisis only belatedly, public policy needs reforms that can mitigate the sudden crisis that arises when a financial institution enters the danger zone and its creditors begin to back away. Finally, if the goal is to reassure the market, it seems selfdefeating to force very troubled firm into receivership in order to aid it (but, as later discussed, that appears to be the Dodd-Frank approach).

\section{B. The Political Economy of Financial Regulation. Agreement is virtually}

universal that lax regulation by all the financial regulators played a significant role in the 2008 financial crisis. But why did this happen? The answer is not that federal financial regulators were incompetent or foolish. Rather, the answer begins with the fact that they were continually on the defensive during the "boom" years after 2000. The period from 2000 on was an era of rapid deregulation. In 2000, Congress passed the Commodities Futures Modernization Act, which deregulated over the counter (“OTC") swaps, including, of course, credit default swaps, withdrawing them from the supervision of both the SEC and the CFTC. In 2004, the SEC adopted its Consolidated Supervised Entity program, which freed the five largest U.S. investment banks that were not part of a bank holding company (e.g., Goldman Sachs, Merrill Lynch, Morgan Stanley, Lehman and 
Bear Stearns) from the SEC's net capital rule. ${ }^{52}$ The result was a sharp increase in leverage at all five firms - exactly at the wrong time from a regulatory standpoint.

Moreover, the industry was pressing for still more deregulation. The message it constantly stressed was that the United States was losing its international competitiveness to other less regulated capital markets (which in blunter terms meant that New York was losing its edge to London, where "light touch" regulation reigned and litigation was disfavored). In 2006, the Committee on Capital Markets Regulation, a blue ribbon body, released its "Interim Report," which called for significant dismantling of the existing regulatory structure in order to restore the U.S.'s capital market competitiveness. ${ }^{53}$ In 2007, Mayor Bloomberg and Senator Charles Schumer of New York issued a similar report (albeit more moderate in tone), which also called for deregulation to protect New York City's role as the world's leading financial center. ${ }^{54}$ In 2008, the Treasury Department issued a provocative study that recommended the consolidation of financial regulators, greater reliance on self-regulation, and reduced enforcement. ${ }^{55}$ Yet, at the same time as these reports were calling for looser, more "principles based" regulation, the first signs of collapse in the subprime mortgage market were already becoming apparent.

\footnotetext{
${ }^{52}$ For a concise discussion of the Consolidated Supervised Entity program and its consequences, see Coffee and Sale, Redesigning the SEC: Does the Treasury Have A Better Idea?, 95 Va. L. Rev. 207, at 735 to 740 .

${ }^{53}$ See Interim Report of the Committee on Capital Markets Regulation (Nov. 30, 2006).

${ }^{54}$ See Jenny Andersen, “U.S. Financial Sector is Losing Its Edge, Report Says,” N.Y. Times, January 22, 2007 (describing Bloomberg/Schumer Report). Many of the criticisms in both these critiques may have been justified, but neither recognized that deregulation carried risks and could produce catastrophe.

${ }^{55}$ See Dep't of Treasury, BLUEPRINT FOR A MODERNIZED REGULATORY STRUCTURE (2008). Professor Sale and I have criticized aspects of this proposal at length elsewhere. See Coffee and Sale, supra note 52, at 749 to 775 .
} 
None of this should surprise us. The collective interest of the financial community at the end of a boom is to keep the boom going. Contrary indicators may be collectively repressed. Moreover, within the major financial institutions, those who had been the architects of the new financial technology (whether asset backed securitization or credit default swaps) had risen in power and prestige. Any call for increased regulation was an implied criticism of them and was met with stubborn hostility. Internal self-criticism within financial institutions only came later, after the crash, when the once proud leaders of these firms had departed in relative disgrace.

In overview, regulatory arbitrage did not drive this process of deregulation, but it did arm those wishing to maintain the deregulation of OTC derivatives and the limited oversight of investment bank leverage with a powerful defense: Increase regulation, they could say, and our bank will gradually shift its operations abroad! Prosperity, it was argued, depended on leaving the financial industry alone and trusting in its enlightened self-regulation.

But, after the crash, deregulation and self-regulation are no longer in vogue. Still, how long will it take for these attitudes to reappear? The answer probably depends on how far off is the next economic boom. Only in a boom period are financial executives treated as omniscient and far-sighted. Recent history shows, however, the swiftness with which attitudes can change. In 2002, Sarbanes-Oxley sailed through both Houses of Congress, receiving an unanimous vote in the Senate. A few years later, it was being blamed by politicians and conservative academics (sometimes in hysterical terms) as a leading cause of the United States' reduced international competitiveness. Predictably, the Dodd-Frank Act will encounter a similar experience. Moreover, far more than the 
Sarbanes-Oxley Act, the Dodd-Frank Act delegates power to administrative agencies, who must over the next two years adopt detailed regulations on a variety of low visibility topics, all of which threaten to reduce the profitability of the financial industry.

Financial executives know that the simplest way to increase bank profitability is to increase leverage. Over the short-run, explicit demands to relax leverage regulation or capital adequacy requirements will not be politically feasible for the industry; instead, the battle will be fought over the loopholes and exceptions to arcane regulations. ${ }^{56}$ But as the crisis fades in the public's memory, the same claims that the U.S. is losing its competitiveness will be raised as a justification for relaxing regulation. To be sure, the model for enlightened relaxed regulation may no longer be London. Instead, the proposed paragon of enlightened minimalist regulation could be Singapore, Hong Kong, or new financial centers elsewhere. But the dynamic will be the same.

As a result, the intensity of regulatory supervision is likely to follow a sine curve: tight regulation after a crash, followed by gradual relaxation thereafter. This cycle could repeat itself, depending on the severity of each crash and the intensity of each boom. The point here is not that regulation is futile, but that it is insufficient to rely on preventive regulation alone. However well-intended, regulation will predictably be outflanked, relaxed, or rendered obsolete by other intervening developments. Thus, other techniques must be used in combination with preventive regulation to reduce the risk of financial

\footnotetext{
${ }^{56}$ This battle will be fought (quietly and not-so-quietly) not only over the implementation of the Dodd-Frank Act, but also over international capital adequacy standards for banks, as negotiations are already well underway with respect to the Basel Committee on Banking Supervision's proposed international accord, known as "Basel III." See Jack Ewing, "Bank Panel Expected to Strike Deal on New Rules," The International Herald Tribune, September 9, 2010 at p. 1.
} 
contagion. The goal must be to reduce the shock of collapse so that one failure does not produce others because of the interconnections among firms.

C. Bounded Rationality: Psychological Limits on Risk Perception. To this point, we have implicitly assumed that the sell side overreached the buy side and that this largely explains the 2008 crisis. The former may have exploited the latter's willingness to rely on ratings agencies or to trust investment bankers; alternatively, moral hazard and agency cost problems may have blinded those on the sell side to the toxic quality of the products they were marketing.

Still, there is another possibility. Particularly because so many banks held onto large quantities of the products they were marketing (either by holding CDOs in their own portfolios or by guaranteeing the obligations of the structured investment vehicles ("SIVs") that they created), a distinct possibility arises that no one understood the level of risk that all were assuming. The failure of AIG fits within this category especially well; even if executive compensation mistakes provide a partial explanation, it remains the case that the management of AIG allowed itself to underwrite most of the subprime market through credit default swaps - without understanding adequately the sudden liquidity risks that could befall them on a ratings downgrade.

In short, it is conceivable that no one knew what they were doing and all underperceived the risk. A number of recent commentators have advanced this perspective, arguing that risk was systematically underestimated. ${ }^{57}$ These arguments

\footnotetext{
${ }^{57}$ See, in particular, Donald Langevoort, Chasing the Greased Pig Down Wall Street: A Gatekeeper's Guide to the Psychology, Culture and Ethics of Financial Risk-taking, (forthcoming in the Cornell Law Review) (available at http://ssrn.com/abstract=1639138) (July 2010); see also Gary Gorton, The Subprime Panic, 15 Eur. Fin. Mgt. 12 (2009); George Akerlof \& Robert Shiller, ANIMAL SPIRITS: How Human Psychology Drives the Economy (2008); Geoffrey
} 
quickly lead into a lengthy exegesis of the individual heuristics and biases that cause individuals and organizations to underperceive risk, and this article will simply note that these commentators have attracted substantial interest, particularly within the still young field of behavioral economics.

But what is the implication of this research for public policy and relevant responses to the financial crisis? The short answer here advanced is that regulators, as well as practitioners, can underestimate risk and respond slowly to mounting evidence of an approaching crisis. Or, they can repress adverse information because its recognition may force them to concede earlier mistakes. If so, one cannot depend exclusively on preventive regulation (or "safety and soundness" regulation in the traditional language of bank regulators). Rather, one needs failsafe remedies, such as industry insurance funds or contingent capital, in order to mitigate the financial crisis when the bubble eventually bursts. Put simply, if bubbles will recur, one needs an "ex post" mechanism outside of the regulatory system to soften their impact.

D. Traditional Crisis Regulation Versus Dodd-Frank's Approach. In the late $19^{\text {th }}$ Century, Walter Bagehot succinctly defined the role of the central banker: to serve as the lender of last resort and thereby prevent a liquidity crisis from creating a financial panic that froze the markets and depressed the economy. ${ }^{58}$ The central banker, he advised, had to quickly distinguish between banks facing a liquidity crisis and those that were truly

Miller \& Gerald Rosenfeld, Intellectual Hazard: How Conceptual Biases in Complex Organizations Contributed to the Crisis of 2008, 33 Harv. J. L. \& Pub. Pol'y 807 (2010); Emilios Avgouleas, The Global Financial Crisis: Behavioral Finance and Financial Regulation: In Search of a New Orthodoxy, 9 J. Corp. L. Stud. 23 (2009).

${ }^{58}$ See Walter Bagehot, LOMBARD STREET: A Description of the Money Market (1873). For a discussion of the U.S. experience with bank panics (which were recurrent prior to the FDIC's creation), see Gary Gorton, Banking Panics and Business Cycles, 40 Oxford Economic Papers 751 (1988). 
insolvent. The latter should be shut down quickly, but the former should have funds made easily available to them (but at a penalty rate of interest) to avert a general panic. In practice, the line between a liquidity crisis and true insolvency has proven difficult to draw, but central bankers have for well over a century generally recognized the wisdom of Bagehot's advice. Because of inherent bank fragility, quick intervention was necessary, and its goal should be to save the fundamentally sound bank, while winnowing out the truly insolvent.

The Dodd-Frank Act appears to turn Bagehot's advice on its head. Essentially, it denies bank regulators the ability to target funds to threatened financial institutions, except in cases where the financial institution is to be liquidated pursuant to the FDIC's resolution authority. Thus, the FDIC can advance funds, or guarantee debts, to those firms under the death sentence of a liquidation, but neither it nor the Federal Reserve can do much to help the potentially solvent firm that is teetering on the brink. Because most financial firms are unlikely to concede that they are insolvent (but may readily acknowledge that they need liquidity), the central banker after Dodd-Frank is unlikely to perform its traditional "lender of last resort" function and must act more as a financial undertaker.

To see this point, one must understand that prior to the Dodd-Frank Act, both the Federal Reserve Board ("FRB”) and the Federal Deposit Insurance Corporation ("FDIC") had authority to make emergency loans to a troubled financial institution to avert its insolvency, and the FRB actually used this authority to bail out AIG. After the DoddFrank Act, both agencies have been greatly restricted in their ability to lend to a failing 
non-bank financial firm, ${ }^{59}$ except to the extent that such a firm is being liquidated pursuant to the special "resolution authority" that the Dodd-Frank Act gives the FDIC. ${ }^{60}$ Why? Essentially, Title II of the Act ("Orderly Liquidation Authority") is an effort to craft an intermediate option between a bankruptcy and a bailout. Title II's compromise, which will apply in the future to non-bank financial firms (such as a Lehman, Bear Stearns or AIG), intends a controlled winding-up of the failing non-bank, rather than a re-organization in bankruptcy. Although the FDIC can advance funds to keep such a firm afloat until the liquidation is completed, neither the FDIC nor the FRB can advance funds to a specific company to enable it to avoid insolvency. ${ }^{61}$ Thus, the Dodd-Frank Act makes FDIC receivership the exclusive route by which such a firm can receive funds from these agencies. This presents a major problem for the firm that is not yet insolvent, but faces a serious liquidity crisis. As just noted, these were the firms that

${ }^{59}$ Section 1101(a)6 of the Dodd-Frank Act restricts the FRB's former authority under Section 13 of the Federal Reserve Act to make emergency loans to a failing institution. Under Section 1101(a)(6), the FRB can make emergency loans "for the purpose of providing liquidity to the financial system, and not to aid a failing financial company." Further, Section 1101(a)(6) provides that such loans must be fully and adequately collateralized (which would have been impossible for an AIG), and it specifically denies the FRB the power to make loans to a "single and specific company" under its emergency lending authority or to make loans "for the purpose of assisting a single and specific company to avoid bankruptcy, resolution authority under Title II of the Dodd-Frank Wall Street Reform and Consumer Protection Act, or any other Federal and State insolvency proceeding." See Section 1101(a)(6). In substance, this language makes explicit that the FRB's emergency lending authority cannot encompass bailout loans to a future AIG or Lehman.

In the case of the FDIC, which is permitted to lend to a "covered financial company" in receivership under Section 204(d) of the Dodd-Frank Act, Section 212(a) ("No Other Funding") of the Dodd-Frank Act bars the provision of funds by the FDIC to such companies outside of a Title II receivership.

${ }^{60}$ Section 204(d) ("Funding for Orderly Liquidation") of the Dodd-Frank Act authorizes the FDIC to make loans to, or to guarantee the obligations of, a "covered financial company" (which term means a company in receivership under Title II), but, as just noted, Section 212(a) precludes lending to such firms outside this receivership context.

${ }^{61}$ See note 59 supra. 
classically bank regulation sought to save. Just as in Viet-Nam, where it was allegedly necessary to "destroy the village to save it," the Dodd-Frank Act may force some firms into unnecessary liquidation in order to qualify for loans.

At this juncture, the utility of contingent capital comes into clearer focus as an alternative means by which to avert unnecessary liquidations. If regulators cannot bail out troubled firms, it is dangerously short-sighted to rely exclusively on safety and soundness regulation. History shows that major financial failures have continued to occur, ${ }^{62}$ and it is predictable that the intensity of financial regulation will eventually be relaxed.

Driving the Dodd-Frank Act's insistence on a FDIC receivership as the only route to creditor repayment was the fear that broader lending authority would lead to moral hazard and public bailouts. Worse yet, the political toxicity of the word "bailout" led Congress to reject FDIC-like private insurance funds that were to be funded by levies on the banks themselves. ${ }^{63}$

\section{The Failsafe Option: Contingent Capital As a Complement to Oversight}

Nothing in what has been said so far challenges the need for "safety and soundness" regulation of financial institutions. The more modest claim is instead that such preventive regulation must be supplemented by additional measures. Precisely because the regulator is not omniscient, the regulator needs additional tools. But, as just seen, the Dodd-Frank Act actually reduces the options available to regulators for dealing

\footnotetext{
${ }^{62}$ For a recent history of such failures, see Anabtawi and Schwarz, supra note 4, at 8-13 (discussing systemic failures since the Great Depression, including Enron and Long-Term Capital Management).

${ }^{63}$ The House version of the Dodd-Frank Act, which passed the House in December, 2009, did contain a significant private insurance fund, but it was dropped at the Conference Committee stage in the enactment of the Dodd-Frank Act. See Section 1609 of H.R. $4173,111^{\text {th }}$ Congress, $1^{\text {st }}$ Sess. (Dec. 11, 2009).
} 
with a financially troubled financial institution in order to prevent public bailouts.

Properly designed, contingent capital can fill much of this void.

\section{A. The Contingent Capital Alternative}

The idea of contingent capital as a means of stabilizing large financial firms is relatively new, and its discussion has been largely confined to financial economists. ${ }^{64}$ Generally, it has been agreed that contingent capital should reduce effective leverage, the risk of a bankruptcy, and the justifications for a bailout. ${ }^{65}$ For these reasons, the Basel Committee on Banking Supervision, the Association for Financial Markets in Europe ("AFME"), and the Squam Lake Working Group have endorsed the concept, and the Financial Stability Board seems to be leaning in its favor. ${ }^{66}$ Lloyd's Banking Group actually issued such a security in 2009 , and Rabobank followed with a larger offering in $2010 .^{67}$

\footnotetext{
${ }^{64}$ See Mark J. Flannery, "No Pain, No Gain: Effecting Market Discipline Via Reverse Convertible Debentures," in H. S. Scott (ed.), CAPITAL ADEQUACY BEYOND BASEL: Banking, Securities and Insurance, (Oxford University Press 2005); Mark J. Flannery, Stabilizing Large Financial Institutions With Contingent Capital Certificates (available at http://ssrn.com/ abstract=1485689) (October 6, 2009); Robert L. McDonald, Contingent Capital With a Dual Price Trigger (available at http://ssrn.com/abstract=1553430) (February 15, 2010). ${ }^{65}$ See, e.g., George Pennacchi, A Structural Model of Contingent Bank Capital (Working Paper 10-04) Federal Reserve Bank of Cleveland (available at http://ssrn.com/abstract=1595080); McDonald, supra note 64; Flannery, supra note 64.

${ }^{66}$ See Damian Paletta, "Idea to Prevent Next Banking Bust?” Wall Street Journal, September 27, 2010 (noting support of Basel Committee, Goldman Sachs, Inc., and others); Harry Wilson, "Bonds Must Take Place of Bail Outs, Says AFME," The Daily Telegraph, August 13, 2010 (explaining AFME's support for contingent capital as most practice alternative; see also Squam Lake Working Group, An Expedited Resolution Mechanism for Distressed Financial Firms: Regulatory Hybrid Securities, (Council on Foreign Relations April 2009). With respect to the Financial Stability Board, which is expected to issue a report shortly, see Bradbery, supra note 21. ${ }^{67}$ See Harry Wilson, supra note 66, (noting that Lloyd's Banking Group issued such a security in 2009 and that the market already refers to this new type of security as "cocos" for "contingent convertibles"); Jackie Ineke, Lee Street, and Fiona Simpson, "Lloyds-trigger happy," European Banks, Morgan Stanley Research, Nov. 5, 2009. In 2010, Rabobank sold a 25 billion euro
} 
Much of the academic discussion has assumed that the mandatory conversion was a means of scaling back the issuer's debt and has therefore focused on the incentives of the issuer to either manipulate the market or increase the firm's level of risk following the issuance of such a security. ${ }^{68}$ Several papers have focused on the mechanics for specifying the conversion ratio and whether a single or a dual price trigger should be used; ${ }^{69}$ and a few commentators have worried about the absence of any clear equilibrium associated with the use of contingent capital. ${ }^{70}$ These are not the issues on which this article will focus. $^{71}$

unsecured ten year bond that would convert into equity if the bank lost $\$ 15$ billion of its roughly $\$ 35$ billion in equity. See Euromoney, April 2010. The interest rate on the bonds was $6.875 \%$ or 351 basis points above the yield on equivalent swaps. On this basis, the offering was easily oversubscribed. For a further description of these offerings, see infra text and note at note 73 . ${ }^{68}$ Pennacchi concludes that a moral hazard incentive does arise following the issuance of contingent capital to increase the firm's level of risk, but that it is less than that which arises on the issuance of subordinated debt. See Pennacchi, supra note 65. To reduce the incentive to manipulate (by persons who might buy the contingent security and short the common stock), some have proposed more complicated designs under which the newly issued security can be repurchased. See George Pennachi, Theo Vermaelen, and Christian C. P. Wolff, Contingent Capital: The Case for COERC's (available at http://ssrn.com/abstract=1656994) (August 11, 2010). But see infra at note 71 .

${ }^{69}$ McDonald favors a dual trigger which would convert the debt only when the firm's own stock price and a stock index price for similar financial institutions both declined to defined levels. See McDonald, supra note 64. He argues that if banks generally are not in distress, there is less reason to spare the individual bank from bankruptcy and that a dual trigger reduces the prospect of price manipulation. The dual trigger may indeed reduce the prospect of manipulation, but if we are focused on systematically significant financial institutions, even the bankruptcy of one could be catastrophic.

${ }^{70}$ See Suresh Sundaresan and Zhenyu Wang, Design of Contingent Capital With a Stock Price Trigger for Mandatory Conversion, Federal Reserve Bank of New York Staff Report No. 448 (May 2010) (arguing that contingent capital proposals do not in general lead to a "unique equilibrium" in equity or contingent capital prices). Sundaresan and Wang recognize, however, that if the bond had a "floating coupon" rate, set at the risk free rate, then this problem would be largely mitigated, and contingent capital becomes "implementable."

${ }^{71}$ Because, as here proposed, the debt security would convert into a preferred stock and not a common stock, its volatility will be far lower and thus the incentive to manipulate should be much weaker. As a result, this paper disregards the manipulation issue. 
Instead, the design here advocated seeks to protect the debt holder from loss on conversion and deliberately impose the burden instead on the common shareholders. This potential wealth transfer is intended to deter the equity from approaching the trigger points at which conversion would occur - and thus disincentivize them from increasing risk or leverage.

To date, commentators have not focused at all on voting rights. This is understandable because if the debt security converts into common stock, the newly issued common stock would predictably come to be owned by the same categories of institutional investors as already held that common stock. ${ }^{72}$ Little would change. Voting rights are, however, the special attraction of using a nonconvertible preferred stock with a fixed return. The holders of such a fixed return security have interests naturally aligned with the debt holders and should vote in a manner consistent with the debt's interests to resist increases in risk. From this starting point, issues about conversion ratios, procedures, and pricing come into a sharper focus, and concerns about wealth transfers between bondholders and common shareholders can be more coherently addressed.

1. The Conversion Formula. In designing such a preferred stock to underlie the bonds, a guiding consideration should be to reduce any financial shock to the debt markets, because shock can be contagious. After all, if contingent capital were required by regulators, the first financial institution to experience a mandatory conversion might be the bellwether for a number of other financial firms that had also entered the danger

\footnotetext{
${ }^{72}$ This is both because some debt investors (for example, money market funds) cannot legally hold common stock and, more generally, because the holders of debt securities tend to be risk averse (or at least want to maintain their prior portfolio balance and so, after conversion, will replace the former debt security that they held with a new debt security by selling the common stock that they receive).
} 
zone, but were not yet in imminent danger of a mandatory conversion. If this is the goal, then it is important that the design of the convertible security eliminate or minimize any wealth transfer from bondholders to common stockholders (although it is acceptable if the reverse wealth transfer occurs from stockholders to the former bondholders because this creates a disincentive for the shareholders to increase the firm's risk level). Symptomatically, the first major transaction in which a contingent capital security was offered to investors involved extraordinary potential writedowns for the bondholders on conversion. $^{73}$

The simplest and most feasible conversion formula would be to convert the bonds into a similar principal amount of preferred stock. Thus, $\$ 1,000,000$ in principal amount of bonds would convert into 10,000 shares of preferred stock with a $\$ 100$ par value. This is an easy decision, because, in the case of preferred stock, the critical issue is how to adjust the dividend rate on the shares to hold the former bondholders harmless. Here, two possibilities can be reasonably debated. First, one could provide in the bond indenture a specific dividend rate on the preferred stock that would be sufficient to cause the preferred stock to trade at par in the market (at least as of the time of the bonds' original issuance). Thus, if the bonds were issued at, say, a 9\% interest rate, it might follow that the dividend rate would be, hypothetically, $12 \%$ (or whatever rate would then permit the preferred stock to trade at par).

\footnotetext{
${ }^{73}$ In the Rabobank transaction in 2010, which is discussed supra at note 67 and infra at notes 89 to 90 , on conversion, "investors lose $75 \%$ of their money." See Louise Bowman, "Bank Capital and Regulation: Damned if you do, damned if you don't," Euromoney, June 2010, at 4. The terms of the offering required redemption of the bonds at $25 \%$. The Rabobank transaction appears to have been marketable only because the bank had an AAA rating, and the risk of conversion was remote. $\underline{\text { Id. }}$.
} 
A conceivable alternative procedure would be to appoint an arbitrator or panel of arbitrators in the indenture that would specify the dividend rate at the time of conversion, instructing them in the bond indenture to select the dividend rate that would enable a nonparticipating preferred stock issued by a company of a similar risk level to trade at par (subject possibly to some ceiling level). This latter alternative could provide a windfall to the bondholders (for example, if interest rates moved upward between the time of issuance of the bonds and their conversion), or it could even pay them less than the first alternative (if interest rates over the same time period fell). Still, it would assure the bondholders that their preferred stock should actually trade closer to par than under the first alternative, and this gives them greater certainty and reduces the prospect that the issuer will seek to force a conversion to exploit the bondholders.

Under either formula, the likely dividend rate on the preferred stock will be higher than the interest rate on the bonds, and conversion will thus increase the servicing costs to the financially strained issuer. This should not concern us from a public policy perspective, because unpaid dividends cannot result in a default, but simply in the buildup of cumulative arrearages. Also, because the likely servicing cost to the issuer should increase under either alternative, there is less reason to fear that the issuer will seek to manipulate its stock price to force a conversion. ${ }^{74}$

2. The Timing of Conversion: All or Incremental? The next important issue is the trigger point or points at which the conversion becomes mandatory. Here, to reduce market shock, incremental conversion might be preferred in a series of steps; for

\footnotetext{
${ }^{74}$ Conceivably, an attractive premium on conversion could create a corresponding incentive for price manipulation by bondholders. But this scenario seems less likely, and management could resist such manipulative efforts by causing their corporation to make stock purchases in the open market.
} 
example, $25 \%$ of the bonds might convert on a $25 \%$ stock price decline from the stock price on the date of the bonds' issuance; another $25 \%$ might convert on a further $25 \%$ decline, and the balance would convert if the stock price fell $75 \%$ (or more) from the original price. ${ }^{75}$ Use of the market price as a trigger supplies an objective measure that is less easily manipulated than accounting standards. Alternatively, a defined widening of credit default spreads on the issuer's debt may supply another potential objective measure. $^{76}$

Other additional triggers might also be used. For example, a rating downgrade of the bonds by a major ratings agency to a level below investment grade might trigger a conversion of some percentage of the bonds (say, 50\%). This would again penalize the shareholders, and not the bondholders, and disincline shareholders from pressuring their firm for increased risk or leverage after the issuance of the bonds.

Possibly the most important rationale for incremental conversion is to enable the use of an early trigger for conversion. If the new preferred shareholders are to be given voting rights in the hope that this will alter corporate governance at the issuer and/or affect managerial preferences, such an issuance cannot come at the twelfth hour if it is to work. Corporate governance changes take time, discussion, and negotiation. Nor is it realistic to make the complete conversion of the debt security into preferred stock depend only on a moderate stock price decline (which might occur for extrinsic reasons and later

\footnotetext{
${ }^{75}$ Just as in the case of a bond sinking fund, this $20 \%$ could be selected by lot. Or, one could provide that all outstanding contingent bonds would be converted pro rata to the extent of $20 \%$. This choice is unimportant.

${ }^{76}$ There is, however, a complication with the use of credit default spreads. Because conversion will reduce the outstanding debt, credit default spreads would be meaningless in the case of the convertible security (as it cannot default). Moreover, the credit default spread on senior, nonconvertible classes of debt may improve (or tighten) as mandatory conversion nears because they are benefitted by the conversion (even if the firm's position has deteriorated).
} 
be reversed). Hence, a series of smaller conversion, beginning at an early point, seem preferable.

Others have suggested that conversion should be triggered by a regulator's decision that additional equity capital was needed. ${ }^{77}$ However, this may place too much faith both in the issuer's accounting and in regulators. Market declines - in stock prices or credit default spreads - seem a more reliable measure of stress (although prudence suggests that the closing stock price should have to remain below the specified level for some brief period - say, three or more trading days - before the conversion trigger would be pulled).

3. Voting Rights. A reasonable debate is equally possible over what voting rights the preferred stock should carry. Often preferred stock is issued on a basis under which it votes only if its dividend is missed. Yet, because the goal here is to create a voting counterweight to the risk-neutral stance of the common stockholders, voting rights need to commence immediately on conversion, without waiting for a default on the preferred dividend as a precondition.

A related choice is how the preferred stock should vote: i.e., with the common as a single class, or, alternatively, as a separate class that would have the right to elect a specified member of directors (say, one quarter of the board). This latter provision would require classification of the board, which would usually require a charter amendment, unless the corporation had a "blank check" preferred stock provision in its certificate of

\footnotetext{
${ }^{77}$ See Flannery (2009), supra note 64 (recommending that conversion of debt security be tied to a decline in the bank's equity ratio). In contrast, McDonald recommends against the use of accounting numbers in the trigger or conversion formulas (and this article agrees). See McDonald, supra note 64, at 1 .
} 
incorporation. ${ }^{78}$ Allowing both classes to vote as a single class has the virtue of simplicity and is less likely to produce a factionalized board of directors.

If a more potent remedy is desired, the preferred could be given multiple votes per share. The case for such a "super-voting" provision is strongest when the initial conversion would likely result in a class of preferred with only $10 \%$ or less of the voting power. Again, such a super-voting provision would have to be authorized by the certificate of incorporation (or by a "blank check" preferred provision authorizing the board to set the terms of the voting rights).

Although the preferred shareholders would be entitled to cumulative arrearages, such arrearages are vulnerable and can be eliminated through mergers and other wellknown techniques. ${ }^{79}$ Thus, to protect this right to cumulative dividends, it would be appropriate to give the preferred an additional voting right: the right to elect as a class some addition percentage of the directors each year that their dividend is omitted. The right to class voting would end once the arrearages were fully paid. On this basis, control of the corporation might pass to the preferred shareholders if the arrearages were not eliminated.

\footnotetext{
${ }^{78}$ Many public corporations may have sufficiently broad "blank check" preferred stock clauses in their corporate certificates of incorporation that they could accommodate such a class voting system without amendment of the certificate. Under the law of most major jurisdictions of incorporation, such a provision may permissibly authorize the board of directors to set the terms, including the dividend rate, voting rights, and other features, of new classes of preferred issued from time to time. See Del. Gen. Corp. Law § 151(g); N.Y. Bus. Corp. Law §§ 402(a)(6); 502(c). These provisions have only been successfully challenged when used to create a class of stock that precludes a hostile takeover. See Unilever Acquisition Corp. v. Richardson-Vicks, Inc., $618 \mathrm{~F}$. Supp. 407 (S.D.N.Y. 1985) (enjoining "blank check" preferred class that had 25 votes per share). ${ }^{79}$ For example, cumulative arrearages can be easily eliminated through a merger with the corporation's wholly owned subsidiary. See Federal United v. Havender, 11 A.2d 331 (Del. 1940) and McNulty v. W\&J Sloane, 54 N.Y.S. 2d 253 (N.Y. Sup. Ct. 1945).
} 
Finally, the contingent capital would have to be issued by the parent holding company, not by the banking subsidiary, as voting rights would have little meaning at a controlled subsidiary.

4. Amount to be Issued. How much contingent capital should a systematically significant financial institution be required to issue? The prudent answer to this question has to be determined not by reference to the institution's long-term liabilities (e.g., other bonds and notes), but in terms of its short-term liabilities (e.g., repos and other short term borrowings, including guarantees that are off the balance sheet). ${ }^{80} \mathrm{~A}$ primary purpose of contingent capital is to dissuade these short-term creditors from refusing to roll over their debt obligations because of a fear of insolvency, and thus the principal amount of the contingent capital that will convert must be sufficient to alleviate those concerns. In practical terms, the significance of this point is that federal regulators may need to negotiate the required amount of contingent capital on a case-by-case basis.

Finally, one inevitable limitation on contingent capital must be acknowledged: It cannot prevent economic failure. Interest and amortization on bonds are fixed costs, which do not affect the decision whether to continue the firm in business. That decision is only rationally based on the firm's ability to recover its variable costs. If a firm's variable costs clearly exceed its revenues, and no turnaround is in sight, the firm will not be saved by converting its bonds into preferred stock, and resolution authority provides the superior mechanism for its liquidation. Thus, the boundaries within which contingent capital can feasibly work are set by whether the firm's ability to recovery its variable costs.

\footnotetext{
80 "Short-term liabilities," as here used, would not include depositors, who arguably are less likely to panic because of the presence of FDIC deposit insurance.
} 


\section{B. Objections and Implementation}

Some objections are foreseeable, and some uncertainties clearly exist. They are briefly discussed below.

1. If the Goal Is to Avert Bankruptcy, Why Not Just Require More Common

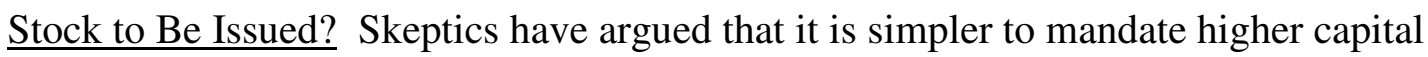
reserves than to use contingent capital. ${ }^{81}$ They have suggested that issuers resist equity issuances because common stock is perceived by the industry as "too expensive." But avoidance of bankruptcy is not the only goal; the other goal is to reduce shareholder pressure on management for acceptance of greater risk. Even if avoidance of bankruptcy were the only goal, the sale of equity securities by a financially distressed issuer can be extremely difficult and may be feasible at only extreme discounts. These expected discounts may deter management from making stock issuances that are in the interests of the public (i.e., the taxpaying public who bear the costs of bailouts). Finally, even if these critics are correct, their argument acknowledges that the industry will resist mandatory issuances of common stock. Given that resistance, use of a convertible preferred may encounter less resistance.

\section{If The Goal Is To Give Voting Rights to Creditors, Why Not Just Authorize}

Bondholders to Vote? Actually, the corporate law of most jurisdictions does not authorize voting by bondholders to elect the board of directors. Delaware is the major exception in permitting the certificate of incorporation to authorize voting by

\footnotetext{
${ }^{81}$ Admati, DeMarzo, Hellwig and Pfleiderer, supra note 9.
} 
bondholders. ${ }^{82}$ But the policy goal here is both to avoid default and bankruptcy as well as to create a new voting constituency. Those goals cannot be fully realized if we simply gave bondholders voting rights to elect directors in limited circumstances (for example, based on ratings downgrades to below investment grade or other financial tests). Although such a power might also reduce stockholder pressure, the prospect of default and a destabilizing bankruptcy would remain if all we did was to give bondholders voting rights. Contingent capital achieves two objectives at once: (1) avoidance of default, and (2) alteration of voting power. In addition, limiting the voting rights to the preferred stock effectively restricts the creditors' voice to times when the corporation is in financial distress. This minimizes the natural conflict between bondholders and shareholders over issues of risk and uses the preferred stock as a late stage failsafe device.

In general, corporate law scholars have assumed that only shareholders should vote because they are the residual claimants on the firm. ${ }^{83}$ But as the corporation becomes insolvent, the board of directors' fiduciary obligation shifts from shareholders to creditors. ${ }^{84}$ Chancellor Allen of the Delaware Chancery Court thus once famously suggested that in the "vicinity of insolvency, a board of directors is not merely the agent

\footnotetext{
${ }^{82}$ Del. Gen. Corp. Law § 221 ("Voting, Inspection and Other Rights of Bondholders and Debentureholders") authorizes certificate of incorporation provisions permitting bondholders to vote. Few other jurisdictions follow Delaware in this regard.

${ }^{83}$ See Frank Easterbrook and Daniel Fischel, Voting in Corporate Law, 26 J. Law \& Econ. 395, 402-404 (1983).

${ }^{84}$ See Credit Lyonnais Bank Nederland N.V. v. Pathe Communications Corporation, 1991 Del. Ch. LEXIS 215, 1991 WL 277613 (Del. Ch. Ct. 1991); Geyer v. Ingersoll Publications Co., 621 A.2d 784 (Del. Ch. 1992). See also Clarkson Co. Ltd. v. Shaheen, 660 F.2d 506 (2d Cir. 1981); Federal Deposit Insurance Corp. v. Sea Pines Co., 692 F.2d 973 ( $4^{\text {th }}$ Cir. 1982). For an overview, see Rutherford Campbell Jr. \& Christopher Frost, Managers' Fiduciary Duties in Financially Distressed Corporations: Chaos in Delaware (and Elsewhere), 32 J. Corp. L. 491 (2007); Laura Lin, Shift of Fiduciary Duty Upon Corporate Insolvency: Proper Scope of Directors' Duties to Creditors, 46 Vand. L. Rev. 1485 (2006).
} 
of the residual risk bearer, but owes a duty to the corporate enterprise." ${ }^{, 85}$ Although

Delaware has not pursued this idea (and indeed may have backed off it), ${ }^{86}$ the "vicinity of insolvency" context remains highly problematic because shareholders do have rational incentives to accept very high risk at this stage. Instead of an "all or nothing" rule that switches the board's fiduciary duty from shareholders to creditors at an imprecisely defined moment, the foregoing proposal designs a compromise mechanism that provides a voice to creditors once into that "vicinity," but still leads to less legal uncertainties.

\section{Will the Tax Law Recognize Contingent Capital as Debt When It May Be}

Converted to Equity? The short answer is yes if some constraints are observed. Although the Internal Revenue Code eyes suspiciously debt instruments that have an "equity flavor," 87 the key point here is that, as of the bonds' issuance, neither the issuer nor the shareholders want the mandatory conversion to be triggered. Such a trigger comes into play only when there is a substantial decrease in the stock price of the common stock, and

${ }^{85}$ See Credit Lyonnais Bank Nederland N.V. v. Pathe Communications Corporation, supra note 83 , at $* 108$.

${ }^{86}$ North American Catholic Education Programming Foundation Inc. v. Gheewalla, 2007 Del. LEXIS 227 (2007).

${ }^{87} \mathrm{New}$ financial products have placed the distinction between debt and equity under increasing strain. The Internal Revenue Service responded to this problem in Notice 94-47, which advised that the Service will "scrutinize" instruments that are designed to be treated as debt for tax purposes but as equity for regulatory purposes. See I.R.S. Notice 94-47, 1994-1 C.B. 357. At present, contingent capital does not count as Tier 1 equity for bank regulatory purposes (although banks would certainly want it to so qualify). The IRS further warned in Notice 94-47 that instruments that are characterized as notes, "but that, on balance, are more equity like are unlikely to qualify as debt for federal income tax purposes." That Notice listed those factors that the IRS considers suspicious, including "whether the rights of the holders of the instrument are subordinate to the rights of general creditors" and "whether the instruments give the holders the right to participate in the management of the issuer." In truth, contingent capital can have these outcomes - but only if a conversion is triggered. For a recent review of the I.R.S.'s positions in this area, see Grace Soyon Lee, What's In a Name?: The Role of Danielson in the Taxation of Credit Card Securitizations, 62 Baylor L. Rev. 110 (2010). 
thus contingent capital is very different from a subordinated convertible debenture (which will be converted to common stock when there is an increase in the stock price).

Moreover, in many of the instances in which the Internal Revenue Service believes that debt should be recharacterized as equity, it is relying on the factor that "there is an identity between the holders of the instruments and stockholders of the issuer." 88 That is not the case with respect to contingent capital, where the purchasers of contingent capital securities would be traditional debt investors.

In short, the bottom line is that even if some less-than-careful attempts to issue contingent capital could raise issues under the Internal Revenue Code, careful tax planning can assure that bonds that are contingently convertible into senior preferred will still be considered debt during the period prior to any such conversion. Probably, the factor that will receive the greatest attention from the IRS is the term of the debt security. here, the shorter the term, the more likely the IRS will accept a debt characterization (as the prospect of conversion is reduced). Suppose then a ten year term is used. On maturity, the issuer can be required to replace the old issuance of contingent capital with a new issuance. Such a cycle of reissuances should satisfy the formalism of tax law.

4. Will Investors Buy Contingent Capital? Since the 2008 crisis, two offerings of contingent capital have already been successfully completed by firms at the opposite ends of the creditworthiness spectrum (Lloyd's Bank and Rabobank). ${ }^{89}$ Although the terms of

\footnotetext{
${ }^{88}$ See Notice 94-47, 1994-1 C.B. 357 (listing the above quoted factor as factor (f) out of eight factors). See also Monon Railroad v. Commissioner, 55 T.C. 345 (1970), acq., 1973-2 C.B. 3. The key feature that led the Service to challenge (unsuccessfully) the debt character of the financial instrument in Monon Railroad was the fifty year term of the bonds. Few debt issuances by public financial institutions are likely to approach this term.

${ }^{89}$ See Louise Bowman, "Bank Capital and Regulation: Damned if you do, damned if you don't," Euromoney, June 2010; “Rabo Sets Tongues Wagging With SCN Issue,” Euromoney, March 19,
} 
the two transactions differed materially, ${ }^{90}$ they hardly demonstrate that investors have yet decided to accept this new product. Three factors have chilled investors' enthusiasm to date: First, the ratings agencies have not yet been willing to give an investment grade rating to, or even to rate, a debt security that may convert into an equity security. ${ }^{91}$ Second, investors could read a financial issuer's desire to issue contingent capital as a signal that it has private knowledge that it is approaching the "vicinity of insolvency." Third, some fixed income investors are simply not legally permitted to hold common shares.

None of these obstacles, however, should prove fatal to contingent capital's use. Rating agency reluctance to rate contingent capital securities appears to be a transitional problem; in all likelihood, if such capital were mandated by regulators, it would appear

2010" (hereinafter, "Rabo"). The two transactions had similarities and differences. In Lloyd's case, the conversion would be triggered when core tier 1 capital fell below 5\%; in the Rabobank offering, the conversion trigger would be pulled if the bank's equity ratio fell below 7\%. See Bowman, supra. Both tests relied then on regulatory requirements, not the stock price decline here recommended. Investors expressed concerns that such regulatory triggers were uncertain in their impact because the formulas used to compute ratios and Tier 1 capital could change over time.

${ }^{90}$ The differences between the two deals were dramatic. In the Lloyd's transaction, the contingent bonds were issued in exchange for existing bonds that Lloyd's was unlikely to be able to repay; hence, the existing bondholders had a stark choice: accept the exchange or expect default. In contrast, Rabobank had a triple-A rating, and observers report that Rabobank was able to market the deal with relative ease because investors saw little prospect that the trigger would ever be pulled. See Bowman, supra note 89 , at 4.

The contingent bonds marketed by Rabobank provided that if Rabobank's equity ratio fell below 7\%, the senior bondholders would "automatically take a 75\% write-down." See Rabo, supra note 89 , at 2 . This implies an immediate gain for the equity when (and if) this trigger was pulled. Although that prospect was deemed very remote in the Rabobank offering, this seems exactly the wrong formula to use and one that may encourage opportunistic behavior by management.

${ }^{91}$ Moody's, for example, refused even to rate the Rabobank deal, noting that: "We have opted not to rate newly issued contingent capital securities with regulatory capital triggers for the time being." See Rabo, supra note 89 , at 2. Despite the lack of any rating, the deal received a "strong response" and was fully sold out according to Morgan Stanley, the placement agent for the deal. 
less novel or suspicious to them. Also, the legal need for institutions to receive investment grade ratings from ratings agencies as a precondition to debt purchases has been largely curtailed by the Dodd-Frank Act, which deleted most statutory references requiring such ratings. ${ }^{92}$ Investor fears about private knowledge on the part of the issuer would also be reduced if the issuer had little choice, because of regulatory requirements or because of regulatory incentives. Then, the issuer's decision to issue contingent capital would not resemble a market signal. Next, even if some investors cannot hold common shares, they can sell their contingent bonds prior to their conversion. This supplies an additional reason why the pricing formula should not require any writedown at the time of conversion, in order to make it easier for such bonds to trade smoothly. Finally, and most importantly, investors who cannot hold common stock (either for legal or economic reasons) may be able to hold a non-convertible, cumulative preferred stock. Indeed, because of institutional style and risk preferences, such investors may much prefer to hold a senior preferred stock, rather than a common stock, if their bonds must be converted. For this reason alone, the conversion should be to a senior security to facilitate the sale of the original bonds.

Of course, some institutional investors may still insist on investment grade ratings, either because they do rely on the ratings agencies or because their boards are concerned about their potential liability under common law standards fiduciary standards, which require them to meet the standards of a "prudent man." But in an increasingly

\footnotetext{
${ }^{92}$ Section 939 ("Removal of statutory references to credit ratings") of the Dodd-Frank Act strikes references requiring specified credit ratings from several federal statutes, including the Investment Company Act of 1940 and the Federal Deposit Insurance Act, and the Securities Exchange Act. Nonetheless, most institutional investors will predictably want investment grade ratings, both because they are risk averse and because they will want to protect their directors or trustees from liability for breach of their fiduciary duties as prudent trustees.
} 
competitive ratings marketplace, ratings agencies are unlikely to turn down opportunities to rate debt securities, particularly if contingent convertibles become a more prevalent asset class. Where the convertible security will received an improved rate of return on conversion, rating agencies could decide that this allowed them to consider such a security "investment grade" (albeit at a low level).

\section{How Will Investors Respond to a Convertible Debenture Convertible Into}

Preferred Stock? Convertible debt is a well-recognized security that over the last thirty years has constituted approximately ten percent of total securities issuances by all U.S. corporations. ${ }^{93}$ But typically, convertible debt offers the investor a two-way play: a straight debt security plus an option feature that offers equity appreciation through conversion. In contrast, as here proposed, this option-like element is missing, as the debt converts only into a fixed return preferred stock (which offers little hope of equity appreciation) and conversion is not at the option of the holder. In all likelihood, this means that a major class of the investors who buy convertible securities - arbitrage and hedge funds - will not be interested in such security so designed. Still, although arbitrage funds began to dominate the convertible debt market in the $1990 \mathrm{~s},{ }^{94}$ their participation has fallen in this sector since the 2008 crisis (as their ability to hedge has been constrained). ${ }^{95}$ At the same time, during the financial crisis, many cash and credit-

\footnotetext{
${ }^{93}$ See Eric Duca, Maria Dutordoir, Chris Veld, Patrick Verwijmeren, Why Are Convertible Bond Announcements Associated With Increasingly Negative Abnormal Stock Returns? An ArbitrageBased Explanation, (available at http://ssrn.com/abstract=1681392) (September 13, 2010) at 1.

${ }^{94}$ See D. Choi, M. Getmansky, and H. Tookes, Convertible Bond Arbitrage, Liquidity, Externalities and Stock Prices, 2 J. Fin. Econ. 227 (2009). These investors typically buy the underpriced convertible security and short the common stock - a hedging strategy unlikely to work where the preferred stock has little potential for upside appreciation.

${ }^{95}$ See Duca, Dutordoir, Veld and Vermijmeren, supra note 93, at 3.
} 
constrained firms apparently found issuing convertibles to "have been the only option." 96 Thus, since 2008, convertible securities have been primarily issued (a) by financially strained companies to (b) longer term investors who were not seeking to arbitrage. ${ }^{97}$ On this basis, contingent convertible securities may be highly attractive to many traditional debt investors, because it offers the higher debt return of subordinated debt plus an even higher dividend return following any conversion.

To be sure, a contingent convertible security that converted into common stock would offer greater equity appreciation (which is less likely in the case of a preferred stock). But because conversion will occur only in a time of financial distress, this option feature may be of less interest to investors. Only investors with a true taste for risk want to see their debt converted into the common stock of a company in distress. Hence, a security convertible into a "safer" preferred stock may be easier to market to institutional investors.

Even if the demand side would be willing to buy a security that converted into a fixed return preferred stock, the supply side (i.e., issuers) may have a different view. Issuers know that preferred stock is not tax-advantaged, because they cannot deduct their dividend payments on such a security from their revenues (as they can in the case of a debt security). Normally, this might be a serious disincentive to its use. But a "contingent capital" security converts only when the firm is in distress. At this point, the interest deduction is likely to be less important because the firm is typically in a loss position (and thus cannot easily use the tax deduction). Moreover, at this point, the fact that the non-payment of the dividend does not create a default is likely to be reassuring to the

\footnotetext{
${ }^{96}$ Id. at 4.

${ }^{97}$ Id. at 3.
} 
firm's management. Hence, although uncertainty remains, it is plausible that both the demand and the supply side would see such a security as attractive, even in the absence of any potential for equity appreciation.

Finally, if financial regulators require it, and large financial issuers must sell it, underwriters can be counted on to make a virtue out of necessity and market it vigorously.

6. Would Managements Resist Contingent Capital? Corporate managers are not known for welcoming ideas conceived by academics and imposed by regulators. Still, hostility to contingent capital should not be assumed. Outside the U.S., some banks have already issued such securities. But, more importantly, if a CEO of a major financial institution were faced with a proxy challenge (presumably pursuant to new SEC Rule 14a-11) led by activists shareholders seeking representation on his board, this CEO might find much to like about the idea of a significant voting block of preferred shareholders, whose rational incentive would be to resist increased risk.

Managers might also wish to make this preferred stock redeemable (in order to maximize their flexibility), but here a conflict does arise between their preferences and the desire of regulators to avoid sudden increases in leverage. As here proposed, the cumulative preferred should not be redeemable. Of course, an issuer can repurchase stock in the market or tender for it, but a major such attempt to alter its balance sheet should come within the jurisdiction of the appropriate bank regulatory agency. As a guideline, if the major ratings agencies would not reduce their ratings on the issuer's debt as a result of such a repurchase of the preferred stock, then such repurchases seem acceptable. 
7. Are There Any Legal Preconditions to the Issuance of Contingent Capital? As

previously noted parenthetically, the issuer's certificate of incorporation must authorize any class of stock and define its rights. But this authorization can be implicit, as "blank check" preferred provisions are authorized by most corporation statutes and delegate to the board the actual determination of the rights, including voting and dividend rights, of any new class. ${ }^{98}$ Such provisions are today extremely common. ${ }^{99}$ Still, in the unusual case where no such provision exists, an amendment to the certification of incorporation would be necessary, and this raises the question: would shareholders approve such a provision?

The most likely answer is that shareholders could be given little choice. Bank regulators can simply give a large financial institution Hobson's choice: either raise significant equity capital by a public offering or issue debt with contingent capital provisions. Because the public offering of common stock would be more dilutive (and in times of economic stress might significantly reduce the stock's market price), shareholders should logically prefer the contingent capital option. But this answer still leaves open whether regulators have the determination to force such a choice on systemically significant financial institutions.

\footnotetext{
${ }^{98}$ See text and note at note 78 supra.

${ }^{99}$ In a recent survey of initial public offerings (or "IPOs"), Professor John Coates found that $86 \%$ of the IPOs in his survey had charters authorizing "blank check" preferred. See John Coates, Explaining Variation in Takeover Defenses: Blame the Lawyers, 89 Calif. L. Rev. 1301, at 1357 (2001). Similarly, Professors Daines and Klausner of Stanford report that "blank check" preferred was authorized in 95\% of IPOs between 1994 and 1997. See Robert Daines and Michael Klausner, Do IPO Charters Maximize Firm Value?: Antitakeover Provisions in IPOs, 17 J. L. Econ. \& Org. 83, 96, tbl 2 (2001). Although these surveys are of recent IPOs, Professor Coates also notes that Investor Responsibility Research Center ("IRRC") data, as of December 31, 1998, showed that "more than $90 \%$ of public companies have adopted charter provisions giving boards 'blank check' authority to issue preferred shares as needed without further shareholder approval. . .." Coates, supra, at 1398.
} 
7. How Should Regulators Implement Contingent Capital? Although few have noticed it, the Federal Reserve Board was expressly authorized by the Dodd-Frank Act to impose "a contingent capital requirement" on both "nonbank financial companies supervised by the Board of Governors" and certain "bank holding companies." 100 Thus, legal authority is not the issue. Rather, the relevant question is the appropriate design of a “contingent capital requirement." Here, one size does not necessarily fit all. From this article's perspective, the goal should be to design a contingent capital standard for systemically significant financial institutions that can both (1) counteract the danger that short-term lenders might suddenly back away (as they appear to have done at Lehman and Bear Stearns ${ }^{101}$ ) and (2) create a voting counterweight to activist investors who may desire the institution to increase its leverage and risk level. This implies using a voting preferred stock instead of common stock.

Besides introducing contingent capital at banks and "shadow" banks, the Federal Reserve needs also to consider its use in the capital structure of the major stock and derivatives exchanges and at the new clearinghouses mandated by the Dodd-Frank Act. Although these institutions may not need to issue debt in any quantity, they concentrate risk and so need to devise ways to avoid default.

\footnotetext{
${ }^{100}$ See Section 165(b)(1)(B) of the Dodd-Frank Act. This is a permissive power, which authorizes the Federal Reserve to establish a "prudential standard" with regard to contingent capital rather than a mandatory requirement. In the case of bank holding companies, the bank holding company must have total consolidated assets "equal to or greater than $\$ 50,000,000,000$." See Section 165(a)(1). In the case of "nonbank financial companies," the Federal Reserve must have first determined to exercise supervision over the institution because of its potential systemic significance. Obviously, the Federal Reserve will do this only in a few cases.

${ }^{101}$ See Gorton, Slapped in the Face by the Invisible Hand: Banking and the Panic of 2007, supra note 49.
} 
Implementation is also possible and desirable at the international level through the Basel Committee on Banking Supervision. If its capital adequacy rules encouraged the use of contingent capital, international convergence on such a standard seems likely, thereby minimizing the prospect for regulatory arbitrage.

This article will not take any position on the status of contingent capital as "Tier One" capital, but, for the future, capital adequacy regulation needs to focus less on the definition of equity and more on the gross leverage ratio between total assets and equity. For this purpose, contingent capital could be given positive weight. If this were done, managerial opposition to rules mandating the use of contingent capital would likely fade.

\section{$\underline{\text { CONCLUSION }}$}

Contingent capital is an idea whose time is coming - both within the United States and internationally. Unlike many other potentially meritorious ideas (which would require legislation), the Federal Reserve Board already has the legal authority to implement a "contingent capital requirement" at its discretion. Moreover, because this is a concept that regulators are considering on a worldwide basis, its adoption could avoid regulatory arbitrage and related problems that may block other sensible reforms. ${ }^{102}$ International convergence on such a reform is possible.

Still, the design of such a reform has not yet received sufficient attention. Here, this article has proposed two ideas that will be controversial: (1) because regulatory

\footnotetext{
${ }^{102}$ For example, proposals for a bank levy to support a private insurance fund face problems if some countries adopt such a proposal and others do not. Those nations that do not tax their banks become essentially free riders on the efforts of the other nations, as the fund will presumably protect all creditors.
} 
failures will occur, ${ }^{103}$ an automatic self-executing safeguard is desirable as a supplement to prudential regulation; and (2) shareholder pressure for short-term profit and higher leverage is best countered by giving the debt holders limited right to vote in times of financial distress. Contingent capital can thus be designed to give us two reforms in one package: a safer, less default-prone capital structure and a counterweight to shareholder pressure. It is not a complete solution by any means, nor a substitute for preventive regulation, but it is a regulatory tool that should be used.

${ }^{103}$ This article has politely refrained from stressing the failures of Drexel Burnham, Long-Term Capital Management, Bear Stearns, Lehman, Enron, WorldCom or the SEC's experience with Bernard Madoff. For such a review, see Anabtauri and Schwarcz, supra note 4. At a minimum, the burden of persuasion is on those who believe that the Dodd-Frank Act will end future regulatory failures. 